Article

\title{
Exploration of the Cs Trapping Phenomenon by Combining Graphene Oxide with $\alpha-\mathrm{K}_{6} \mathbf{P}_{2} \mathrm{~W}_{18} \mathrm{O}_{62}$ as Nanocomposite
}

\author{
Bangun Satrio Nugroho ${ }^{1,2}$, Akane Kato ${ }^{2}$, Chie Kowa ${ }^{2}$, Tomoya Nakashima ${ }^{2}$, Atsushi Wada ${ }^{2}$, \\ Muh. Nur Khoiru Wihadi ${ }^{3,4}$ (D) and Satoru Nakashima $1,2,5, * \mathbb{D}$ \\ 1 Radioactivity Environmental Protection Course, Phoenix Leader Education Program, Hiroshima University, \\ 1-1-1 Kagamiyama, Higashi-Hiroshima 739-8524, Japan; d192886@hiroshima-u.ac.jp \\ 2 Department of Chemistry, Graduate School of Science, Hiroshima University, 1-3-1 Kagamiyama, \\ Higashi-Hiroshima 739-8526, Japan; kato.akane@jaea.go.jp (A.K.); c.k_0715_titty@icloud.com (C.K.); \\ hakatomo0601@gmail.com (T.N.); m204479@hiroshima-u.ac.jp (A.W.) \\ 3 Department of Chemistry, Faculty of Military Mathematics and Natural Science, The Republic of Indonesia \\ Defense University, Bogor 16810, Indonesia; nur.wihadi@idu.ac.id \\ 4 National Research and Innovation Agency (Badan Riset dan Inovasi Nasional) of The Republic of Indonesia, \\ Kawasan Puspiptek, Serpong, Tangerang 15314, Indonesia \\ 5 Natural Science Center for Basic Research and Development, Hiroshima University, 1-4-2 Kagamiyama, \\ Higashi-Hiroshima 739-8526, Japan \\ * Correspondence: snaka@hiroshima-u.ac.jp
}

\section{check for}

updates

Citation: Nugroho, B.S.; Kato, A.; Kowa, C.; Nakashima, T.; Wada, A.; Wihadi, M.N.K.; Nakashima, S. Exploration of the Cs Trapping Phenomenon by Combining Graphene Oxide with $\alpha-\mathrm{K}_{6} \mathrm{P}_{2} \mathrm{~W}_{18} \mathrm{O}_{62}$ as Nanocomposite. Materials 2021, 14, 5577. https://doi.org/10.3390/ ma14195577

Academic Editor: Alexander N. Obraztsov

Received: 19 August 2021 Accepted: 21 September 2021 Published: 26 September 2021

Publisher's Note: MDPI stays neutral with regard to jurisdictional claims in published maps and institutional affiliations.

Copyright: (c) 2021 by the authors. Licensee MDPI, Basel, Switzerland. This article is an open access article distributed under the terms and conditions of the Creative Commons Attribution (CC BY) license (https:// creativecommons.org/licenses/by/ $4.0 /)$.
Abstract: A graphene oxide-based $\alpha-\mathrm{K}_{6} \mathrm{P}_{2} \mathrm{~W}_{18} \mathrm{O}_{62}$ (Dawson-type polyoxometalate) nanocomposite was formed by using two types of graphene oxide (GO) samples with different $\mathrm{C} / \mathrm{O}$ compositions. Herein, based on the interaction of GO, polyoxometalates (POMs), and their nanocomposites with the Cs cation, quantitative data have been provided to explicate the morphology and Cs adsorption character. The morphology of the GO-POM nanocomposites was characterized by using TEM and SEM imaging. These results show that the POM particle successfully interacted above the surface of GO. The imaging also captured many small black spots on the surface of the nanocomposite after Cs adsorption. Furthermore, ICP-AES, the PXRD pattern, IR spectra, and Raman spectra all emphasized that the Cs adsorption occurred. The adsorption occurred by an aggregation process. Furthermore, the difference in the $\mathrm{C} / \mathrm{O}$ ratio in each $\mathrm{GO}$ sample indicated that the ratio has significantly influenced the character of the GO-POM nanocomposite for the Cs adsorption. It was shown that the oxidized zone ( $\mathrm{sp}^{2} / \mathrm{sp}^{3}$ hybrid carbon) of each nanocomposite sample was enlarged by forming the nanocomposite compared to the corresponding original GO sample. The Cs adsorption performance was also influenced after forming a composite. The present study also exhibited the fact that the sharp and intense diffractions in the PXRD were significantly reduced after the Cs adsorption. The result highlights that the interlayer distance was changed after Cs adsorption in all nanocomposite samples. This has a good correlation with the Raman spectra in which the second-order peaks changed after Cs adsorption.

Keywords: graphene oxide; Dawson-type polyoxometalate; cesium; $\mathrm{sp}^{2} / \mathrm{sp}^{3}$ carbon domain; nanocomposite

\section{Introduction}

The destruction of the reactor cores of the Fukushima Daiichi Nuclear Power Plant (FDNPP) ten years ago has had a large influence on the environment. Many researchers predicted the quantity of released material [1] and modeling of the radiation fallout immediately [2]. It is important to consider the radioactive isotopes delivered to the agriculture area [3], tap water [4], and forest area [5]. The subject of considerable concern for the people is the possibility of the radiation exposure to their body. Both the external exposure and internal exposure have radiological consequences that can cause cancer [6,7]. Therefore, it is an essential task to treat and decontaminate the contaminated environment. 
${ }^{137} \mathrm{Cs}$, which has a half-life of 30 years, is one of the nuclides that has been found in the contaminated area [8]. The ${ }^{137} \mathrm{Cs}$ originated from the Tokyo Electric Power Company (TEPCO) FDNPP accident [9]. Many studies have investigated how to handle radioactive cesium as a crucial radioisotope [10]. Chemical adsorption methods that use composites [11] and clay [12] to catch the Cs are the techniques suggested in many papers. According to these methods, the adsorption mechanism emerges as an important concept (such as the hydroxyl-interlayered vermiculate, $3 \mathrm{D}$ microporous composite) and encourages the synthesis of new material. Therefore, the goal of this work is to create a new sorbent material, which has an ability to adsorb the Cs with high efficiency. As is well known, the skeleton of GO having different oxygen functional groups can be considered as a bonding point [13]. Based on that, the chemical modification opens up the idea for tailoring the graphene oxide (GO) with another compound.

Zilong Liu et al. (2019) investigated GO as a novel carbonaceous material and found that the GO surface has an interesting interaction using a polar $-\mathrm{COO}(\mathrm{H})$ and non-polar $\left(-\mathrm{CH}_{3}\right)$ group in order to adsorb different kinds of cations (charge, size, complexing capability) by a proposed ion-bridging mechanism [14]. Another important thing is the solubility of GO in the diverse range of solvents, including water due to the hydroxyl, epoxide functional group and carboxyl group attached on the surface and the sheet edge [15,16].

On the other hand, polyoxometalates (POMs) provide an excellent, robust, and discrete material, which has reversible multi-electron redox properties [17]. Some researchers have employed POMs as a potential Cs adsorption material by using a cation exchange mechanism [18]. For example, it was investigated that the interaction of $\mathrm{Cs}^{+}$with POMs makes it easier to enter and diffuse through the solid-state structure compared to other types of cations by considering the dehydration enthalpy and hydration radius of the cations [19]. The $\mathrm{K}_{6} \mathrm{P}_{2} \mathrm{~W}_{18} \mathrm{O}_{62}$ as a Dawson-type compound has an anionic molecular framework constructed by two phosphates, 18 tungstates surrounding a central potassium. POM has a large molecular size [20] and high potential to reduce [17], and it is a structurally well-defined oxide cluster anion. Furthermore, R.D. Gall et al. confirmed that POM particles could easily be adsorbed on the carbon material [21]. It is also proved by previous study that the anionic $\mathrm{PW}_{12}$ cluster can be adsorbed on the reduced GO and can improve the dispersibility of water on the reduced graphene sheet [22].

Considering the tremendous properties of GO and $\alpha-\mathrm{K}_{6} \mathrm{P}_{2} \mathrm{~W}_{18} \mathrm{O}_{62}$, it is highly desirable to synthesize a new nanocomposite with $\mathrm{Cs}$ adsorption ability using the GO and POMs [23]. In this study, two types of GO samples were employed. One is GO, which has a large amount of carbon $(\mathrm{C})$, and the other is $\mathrm{GO}$, which has a large amount of oxygen $(\mathrm{O})$. They have a variant $\mathrm{sp}^{2} / \mathrm{sp}^{3}$ structure. These GOs can be produced by controlling the oxidation degree, which depends on several factors such as the reaction condition, oxidizing agent, and graphite source [24]. It has been known that the GO structure is not precisely determined because of a variety of local arrangements of functional groups [25,26]. Each GO sample was incorporated with $\alpha-\mathrm{K}_{6} \mathrm{P}_{2} \mathrm{~W}_{18} \mathrm{O}_{62}$. We investigated the interaction of $\mathrm{Cs}^{+}$ with the nanocomposite by characterizing the surface structure of the composite material and also by considering the adsorption capacity of the nanocomposite for radioactive Cs. Each property in each material is expected to synergistically strengthen the adsorption capacity of the nanocomposite. A high Cs adsorption capacity was clearly achieved by using the nanocomposite.

\section{Materials and Methods}

\subsection{Materials}

All raw chemicals were reagent grade and were used without purification, and distilled water was used in all experiments. Graphite, $\mathrm{Na}_{2} \mathrm{WO}_{4} \cdot 2 \mathrm{H}_{2} \mathrm{O}, \mathrm{CsCl}$, and methanol were purchased from Sigma Aldrich Chemistry. $\mathrm{NaNO}_{3}, \mathrm{H}_{2} \mathrm{SO}_{4}, \mathrm{HCl}, \mathrm{H}_{3} \mathrm{PO}_{4}$, and $\mathrm{KCl}$ were purchased from Fuji Film Wako Pure Chemical Corporation. $\mathrm{KMnO}_{4}$ and $\mathrm{H}_{2} \mathrm{O}_{2}$ were purchased from the Tokyo Chemical Industry. 


\subsection{Characterizations}

Fourier transform infrared spectroscopy (FT-720, HORIBA, Ltd., Kyoto, Japan), powder X-ray diffraction measurement (Rigaku, Thermo plus, XRD-DSC II, Tokyo, Japan), and Raman spectroscopy (Raman spectrometer HORIBA, Ltd., T64000, Kyoto, Japan) were conducted to characterize the functional groups, crystallinity, number of layers of GO, size of GO samples, interlayer distance, and the quality of samples. Scanning electron microscope (SEM) (ultra-high resolution field emission scanning electron microscope device (Hitachi High-Technologies Corporation, S-5200, Tokyo, Japan)), EDAX (Genesis XM2, Tokyo, Japan), transmission electron microscopy (TEM) (ultra-high resolution transmission electron microscope (JEOL Ltd., JEM-2010, Tokyo, Japan)) were performed to collect imaging data of the samples. ICP-AES (atomic emission spectroscopy) (SPS3500, SII Nanotechnology Inc., Tokyo, Japan) was used to calculate the adsorption capability of the samples.

\subsection{Synthesis of Graphene Oxide}

All GO samples were synthesized using the modified Hummers method [27]. A pre-cooling procedure was implemented by keeping all the reagents and solvent in the refrigerator for one night before the synthesis process [28]. In order to start the synthesis process, first, a graphite $(1.0 \mathrm{~g})$ and $\mathrm{NaNO}_{3}(1.5 \mathrm{~g})$ were put into the vial. Then, a concentrated $\mathrm{H}_{2} \mathrm{SO}_{4}(50 \mathrm{~mL})$ was added carefully. We stirred the mixture for $30 \mathrm{~min}$ at room temperature. In this step, the color was blackish green. Then, we put the mixture in the refrigerator for $30 \mathrm{~min}$ to keep it in the cooling condition below $10^{\circ} \mathrm{C}$. After that, going to the critical step, we added $\mathrm{KMnO}_{4} 4.0 \mathrm{~g}$ slowly and carefully. Then, we stirred it for about $20 \mathrm{~min}$ and then set the temperature at $35^{\circ} \mathrm{C}$ under stirring for $2 \mathrm{~h}$. After this reaction, the color of the solution became brown. We diluted the mixture with $80 \mathrm{~mL}$ of distilled water with stirring for $15 \mathrm{~min}$. Then, we continued stirring for the other $30 \mathrm{~min}$ at room temperature. We added $150 \mathrm{~mL}$ of distilled water slowly and carefully with stirring for $15 \mathrm{~min}$. After that, $12 \mathrm{~mL}$ of $30 \% \mathrm{H}_{2} \mathrm{O}_{2}$ was dropped carefully to the solution. A large number of bubbles were released. The solution became golden yellow. The solid particle was filtered, washed using $5 \% \mathrm{HCl}$, and followed by using distilled water. We dried the solid at $60{ }^{\circ} \mathrm{C}$ for $24 \mathrm{~h}$. In order to distinguish each GO sample, we termed these GO samples by index number, which have different amounts of $C$ based on elemental analysis. There are two types of $\mathrm{GO}$ sample based on $\mathrm{C} / \mathrm{O}$ composition. The $\mathrm{GO}_{\mathrm{c} 70}$ and $\mathrm{GO}_{\mathrm{c} 72}$ have $70-72 \mathrm{wt} \% \mathrm{C}$ element, while $\mathrm{GO}_{\mathrm{c} 39}$ and $\mathrm{GO}_{\mathrm{c} 40}$ have $\approx 39 \mathrm{wt} \% \mathrm{C}$ element.

\subsection{Synthesis of $\alpha-K_{6} P_{2} W_{18} O_{62}$}

The $\alpha-\mathrm{K}_{6} \mathrm{P}_{2} \mathrm{~W}_{18} \mathrm{O}_{62}$ was synthesized according to the modified Nadjo method [29]. The synthesis route started with dissolving the starting material, $\mathrm{Na}_{2} \mathrm{WO}_{4} \cdot 2 \mathrm{H}_{2} \mathrm{O} 15 \mathrm{~g}$ into $17.5 \mathrm{~mL}$ of distilled water. We vigorously stirred for $15 \mathrm{~min}$ until the cloudy solution became limpid. This was followed by an acidification process: $\mathrm{HCl} 4 \mathrm{M}(12.5 \mathrm{~mL})$ was added dropwise for $45 \mathrm{~min}$ carefully. In this process, white precipitate was formed. In order to avoid agglomeration and to disperse homogenously during the acidification process, the vigorous stirring was performed. We checked the $\mathrm{pH}$ to be around 6-7. Then, $2 \mathrm{M} \mathrm{H}_{3} \mathrm{PO}_{4}$ $(12.5 \mathrm{~mL})$ was added, and we checked the $\mathrm{pH}$ to become around 2-3. The solution was refluxed for $24 \mathrm{~h}$; then this solution was cooled at room temperature for a while. Then, $7.5 \mathrm{~g}$ of $\mathrm{KCl}$ was added to the solution. Afterwards, this solution was filtered off by paper filtration, and the crude material was obtained. Then, we dissolved it into $32.5 \mathrm{~mL}$ of distilled water, and the solution became limpid. The next reflux process was performed at $80^{\circ} \mathrm{C}$ for $72 \mathrm{~h}$. Then, it was cooled at room temperature. The last step was keeping the solution in the refrigerator, and after $24 \mathrm{~h}$, the well-behaved crystals of $\alpha-\mathrm{K}_{6} \mathrm{P}_{2} \mathrm{~W}_{18} \mathrm{O}_{62}$ were produced $(6.5 \mathrm{~g})$. 


\subsection{Synthesis of GO-POM Composite}

The composite sample was distinguished into eight types of composite. Each composite was produced by incorporating the $\mathrm{GO}$ sample $\left(\mathrm{GO}_{\mathrm{c70}}, \mathrm{GO}_{\mathrm{c72}}, \mathrm{GO}_{\mathrm{c39}}\right.$, and $\left.\mathrm{GO}_{\mathrm{c} 40}\right)$ with Dawson-type POM. The GO-POM composite was generated in two different concentration ratios (concentration ratios of GO:POM: 1:8 and 4:1). The constitution is summarized in Section 3.7.2. These treatments (different concentration ratios of GO:POM) were employed in order to investigate the role of GO and Dawson-type POM in the Cs adsorption and to know the proper composition. In this synthesis process, mixed solvent was used with the ratio 1:1 (distilled water/methanol). The GO aqueous dispersion in the first concentration condition (1:8) was prepared by dispersing $1 \mathrm{~g}$ of GO into the solvent $(100 \mathrm{~mL})$ with sonification treatment for $5 \mathrm{~min}$. Then, we prepared the POM solution by dissolving $1 \mathrm{~g}$ of $\alpha-\mathrm{K}_{6} \mathrm{P}_{2} \mathrm{~W}_{18} \mathrm{O}_{62}$ into the solvent $12.5 \mathrm{~mL}$. Afterwards, we poured the POM solution into the $\mathrm{GO}$ suspension vial, added diluted $\mathrm{HCl}$ to adjust the $\mathrm{pH}$ in the range 2-3, and then vigorous stirred for $24 \mathrm{~h}$. In the second concentration condition (4:1), we prepared the GO solution by dispersing GO $(0.5 \mathrm{~g})$ into the solvent $(25 \mathrm{~mL})$ with a sonification treatment for $5 \mathrm{~min}$. The POM solution was prepared by dissolving the $\alpha-\mathrm{K}_{6} \mathrm{P}_{2} \mathrm{~W}_{18} \mathrm{O}_{62}$ $0.5 \mathrm{~g}$ into the solvent $(100 \mathrm{~mL})$. The POM solution was poured into the GO suspension; then, we added diluted $\mathrm{HCl}$ to adjust the $\mathrm{pH}$ in the range 2-3 and after that stirred for $24 \mathrm{~h}$. Finally, the solid material was collected by using filter paper and dried at $90{ }^{\circ} \mathrm{C}$ for $24 \mathrm{~h}$. Then, the composite product was indexed based on the value of the $\mathrm{C}$ element of GO (c70, c72, c39, and c40 due to elemental analysis) and the concentration ratio of GO/POM (1:8 and 4:1) in order to distinguish each composite's name, as follows: $\left[\mathrm{GO}_{70} \mathrm{POM}\right]_{18}$, $\left[\mathrm{GO}_{70} \mathrm{POM}\right]_{41},\left[\mathrm{GO}_{72} \mathrm{POM}\right]_{18},\left[\mathrm{GO}_{72} \mathrm{POM}\right]_{41},\left[\mathrm{GO}_{39} \mathrm{POM}\right]_{18},\left[\mathrm{GO}_{39} \mathrm{POM}\right]_{41},\left[\mathrm{GO}_{40} \mathrm{POM}\right]_{18}$, and $\left[\mathrm{GO}_{40} \mathrm{POM}\right]_{41}$. Contant's group reported the hydrolytic stability of Dawson-type POM depending on the acidity of the solution. That is, Dawson-type POM was stable at $\mathrm{pH}$ lower than 6 , and when the $\mathrm{pH}$ increased above 6, the formation of lacunary species occurs [30]. In the case of our system, preparation and adsorption experiments were performed at $\mathrm{pH}$ lower than 5. Therefore, the Dawson-type POM was stable in the present solution.

\subsection{Adsorption Experiment}

The cesium adsorption was conducted as below. First, $0.08 \mathrm{~g}$ of each sample (POM, GO samples, GO-POM composites) was dispersed into $30 \mathrm{~mL}$ of distilled water with sonification treatment for $5 \mathrm{~min}$. Second, $0.6 \mathrm{~g}$ of $\mathrm{CsCl}(3.6 \mathrm{mmol})$ was added to the solution. Then, the mixture was stirred for $24 \mathrm{~h}$.

The performance of Cs adsorption was analyzed by using ICP optical emission spectroscopy. The solid adsorbent was separated from the solution by using paper filtration. The measurement was conducted in duplicate in each sample solution. The adsorption efficiency was calculated by Equation (1), and the adsorption capacity was calculated by Equation (2).

$$
\begin{gathered}
\text { Adsorption efficiency }(\% \text { Ads.eff. })=\frac{\left(C_{0}-C_{t}\right)}{C_{0}} \times 100 \\
\text { Adsorption capacity }=\frac{\% A d s . e f f . \times C_{0}}{W}
\end{gathered}
$$

where $C_{0}(\mathrm{mmol} / \mathrm{L})$ is the initial concentration of $C s$, and $C_{t}(\mathrm{mmol} / \mathrm{L})$ is the remained concentration of $\mathrm{Cs}$ in the solution after treatment. $W(\mathrm{~g})$ is the dry weight of the adsorbent used in the adsorption experiment.

\section{Results and Discussion}

\subsection{Elemental Analysis}

Table 1 shows the results of elemental analysis of $\mathrm{GO}_{\mathrm{c70}}, \mathrm{GO}_{\mathrm{c72}}, \mathrm{GO}_{\mathrm{c} 39}$, and $\mathrm{GO}_{\mathrm{c} 40}$. It can be seen that the $\mathrm{GO}_{\mathrm{c} 70}$ and $\mathrm{GO}_{\mathrm{c} 72}$ have $70-72 \mathrm{wt} \% \mathrm{C}$ element, while $\mathrm{GO}_{\mathrm{c} 39}$ and $\mathrm{GO}_{\mathrm{c} 40}$ have $\approx 39 \mathrm{wt} \% \mathrm{C}$ element. In the synthesis process, there is one thing that might make the sample a bit different. In the treatment of $\mathrm{KMnO}_{4}$, especially for $\mathrm{GO}_{\mathrm{c} 39}$ and 
$\mathrm{GO}_{\mathrm{c} 40}$, the $\mathrm{KMnO}_{4}$ was treated more carefully (one minute stop, one minute go). It was shown that the degree of oxidation was controlled by the controlled oxidation process. In particular, it can be assumed that there is a difference in structure between the two types of GO. $\mathrm{GO}_{\mathrm{c} 70}$ and $\mathrm{GO}_{\mathrm{c} 72}$ indicating few oxygen defects in the structure have an important contrast with $\mathrm{GO}_{\mathrm{c} 39}$ and $\mathrm{GO}_{\mathrm{c} 40}$. However, deeper characterization is still required, since the oxygen defect is not only the case. As emphasized in the previous literature, there is no evident relation between the oxidation degree and ordered domain that is exhibited in the Raman spectrum [31].

Table 1. Elemental analysis of GO sample.

\begin{tabular}{cccccc}
\hline Sample & $\mathbf{C} \%$ & $\mathbf{H} \%$ & $\mathbf{N} \%$ & $\mathbf{O} \%$ & $\mathbf{C} / \mathbf{O}$ \\
\hline $\mathrm{GO}_{\mathrm{c} 70}$ & 70.87 & 7.95 & - & 21.18 & 3.34 \\
\hline $\mathrm{GO}_{\mathrm{c} 72}$ & 72.04 & 8.07 & - & 19.89 & 3.61 \\
\hline $\mathrm{GO}_{\mathrm{c} 39}$ & 39.28 & 2.76 & 0.27 & 57.69 & 0.68 \\
\hline $\mathrm{GO}_{\mathrm{c} 40}$ & 39.61 & 2.58 & 0.25 & 57.56 & 0.69 \\
\hline
\end{tabular}

\subsection{FT-IR Spectra}

Figures S6-S8 (see supporting information) show the FT-IR spectra of GO and Dawsontype compounds. The Dawson-type POM was successfully produced by the Nadjo synthesis route. The IR absorptions of the present $\alpha-\mathrm{K}_{6} \mathrm{P}_{2} \mathrm{~W}_{18} \mathrm{O}_{62}$ are similar with those of the literature [29]. All the GO samples exhibit a broad absorption band of $\mathrm{O}-\mathrm{H}$ stretching vibration around $3400 \mathrm{~cm}^{-1}, \mathrm{C}=\mathrm{C}$ bond stretching at around $1620 \mathrm{~cm}^{-1}, \mathrm{C}=\mathrm{O}$ vibration at around $1720 \mathrm{~cm}^{-1}$, C-O vibration band at around $1420 \mathrm{~cm}^{-1}$, and epoxides at $1200-1250 \mathrm{~cm}^{-1}$. In addition, the vibration band at around $830 \mathrm{~cm}^{-1}-850 \mathrm{~cm}^{-1}$ was detected especially in $\mathrm{GO}_{\mathrm{c} 39}$ and $\mathrm{GO}_{\mathrm{c} 40}$ samples. This band might be assigned as the $\mathrm{C}-\mathrm{Cl}$ vibration band as reported in the other work [32]. However, the $\mathrm{C}-\mathrm{Cl}$ vibration band is unexplained, because in this work, there is no other additional treatment that refers to the addition of $\mathrm{Cl}$. Since the GO is a nonstoichiometric compound, the structure analysis is quite difficult, and the variety of the composition depends on the synthesis condition. It can be assumed that the remaining $\mathrm{Cl}$ impurity is coming from laboratory glass material. The difference in the degree of oxidation was revealed between $\mathrm{GO}_{\mathrm{c} 70}, \mathrm{GO}_{\mathrm{c} 72}$, and $\mathrm{GO}_{\mathrm{c} 39}$, and $\mathrm{GO}_{\mathrm{c} 40}$; i.e., an epoxide signal was seen in the $\mathrm{GO}_{\mathrm{c} 39}$ and $\mathrm{GO}_{\mathrm{c} 40}$ samples.

\subsection{Morphology of GO}

TEM imaging and SAED diffraction are used to draw the structural model in each GO sample, as shown in Figure 1. For TEM image measurement, $200 \mathrm{kV}$ was applied in each sample. Under this condition, the morphologies of the GO samples were shown to be lamellar, with wrinkles and overlaps, and they were also found to be stable. The image indicates that the some GOs had been exfoliated. This is in agreement with the previous research in which both wrinkles and overlaps are essential features of GO-based bulk material [33]. The sharp spots in an SAED pointed out the crystalline region in GO. Especially $\mathrm{GO}_{\mathrm{C} 72}$ shows a typical diffraction pattern representing the crystalline nature of the GO sample. The present SAEDs are in agreement with the previous work that presented the amorphous region (see Figure 1(A1,C1)) and crystalline region (see Figure 1(B1)) in the GO sample [34]. Particularly, the amorphous zone is associated with the presence of the $\mathrm{sp}^{2} / \mathrm{sp}^{3}$ carbon cluster (see Section 3.7.2) in all the GO samples [35]. In the other imaging using SEM measurement, it is shown in Figure 1d,e that the GO sample consists of several layers (see Table S2, supporting information). Previous work emphasized that the morphology and quality of the multilayers of GO depend on several factors such as the source of graphite, degree of oxidation, and reaction condition [36]. All these GO samples are aligned with a few layers of GO in the previous work [37]. 

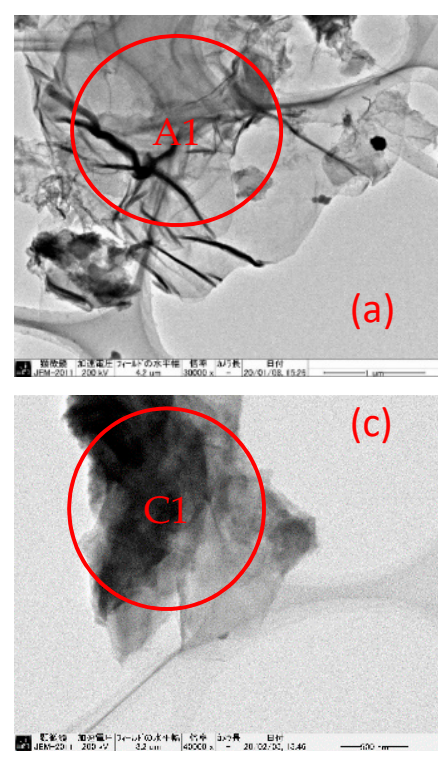
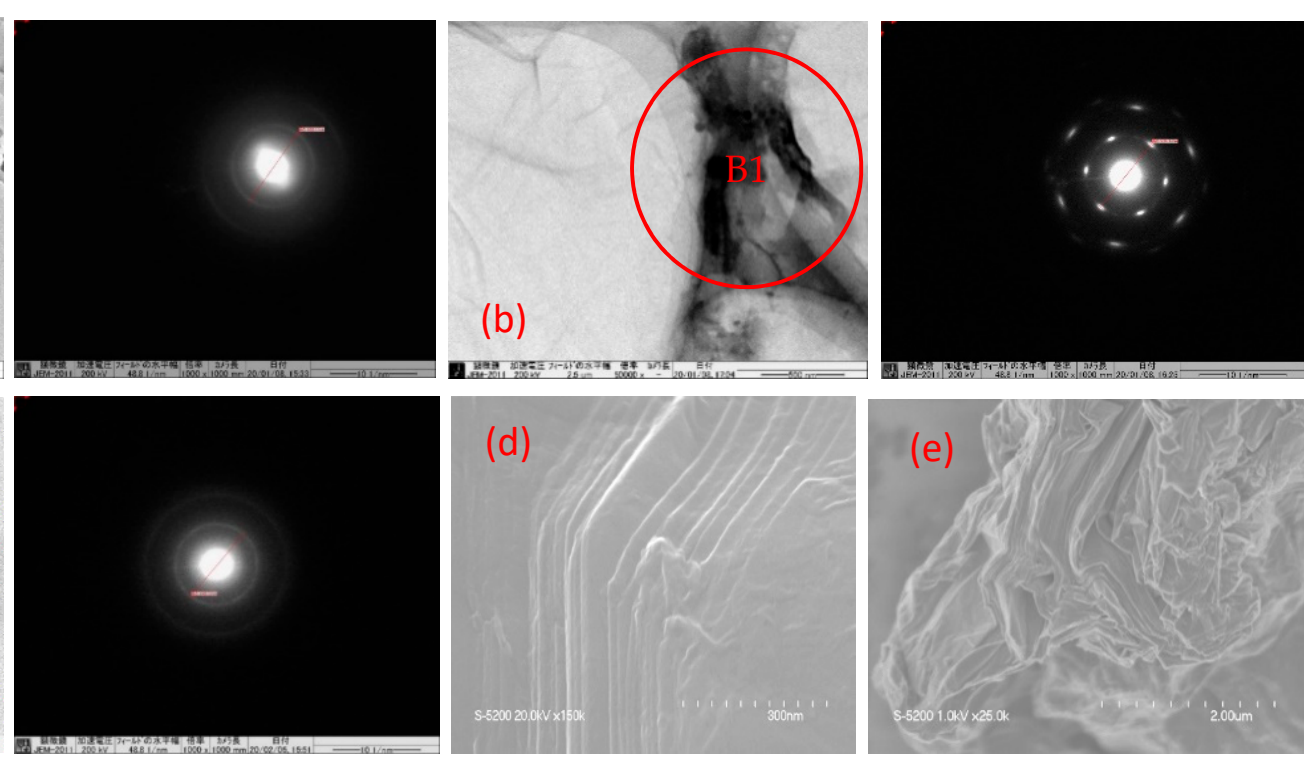

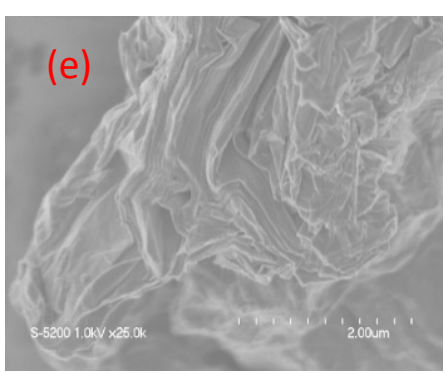

Figure 1. TEM imaging of (a) $\mathrm{GO}_{\mathrm{c} 70}$, (b) $\mathrm{GO}_{\mathrm{c} 72}$, and (c) $\mathrm{GO}_{\mathrm{c} 39}$ and SEM imaging of (d) $\mathrm{GO}_{\mathrm{c} 39}$, (e) $\mathrm{GO}_{\mathrm{c} 40}$, and SAED pattern from the location $(\mathbf{A 1}, \mathbf{B 1}, \mathbf{C 1})$ marked in pictures $(\mathbf{a}-\mathbf{c})$, respectively.

\subsection{Morphology of GO-POM Composite and Its EDS Map}

The SEM image of the GO-POM nanocomposite and its EDS map are shown in Figure 2 and Figures S1 and S2 (see supporting information). Figure 2a shows the SEM of $\left[\mathrm{GO}_{70} \mathrm{POM}\right]_{41}$, and Figure $2 \mathrm{~b}-\mathrm{d}$ show the $\mathrm{W}, \mathrm{O}, \mathrm{C}$ element distribution, respectively. Tungsten is dominantly originated from the $\alpha-\mathrm{K}_{6} \mathrm{P}_{2} \mathrm{~W}_{18} \mathrm{O}_{62}$ particle, and carbon is coming from the GO. The result suggests that the tungsten, oxygen, and carbon elements were homogeneously distributed in the GO-POM nanocomposite, showing the successful combination between GO and POM [38]. This phenomenon was also confirmed by TEM measurement. Figure 2e show the homogenous POM particle in the surface area of GO after forming a composite. The SEM image of $\left[\mathrm{GO}_{70} \mathrm{POM}\right]_{41}$ (Figure 2e) is darker than that of the original $\mathrm{GO}_{\mathrm{C} 70}$ (Figure 2f). The formation of a layer after forming the composite $\left[\mathrm{GO}_{70} \mathrm{POM}\right]_{41}$ (Figure 2(E1)) was confirmed by comparing it with original $\mathrm{GO}_{\mathrm{C} 70}$ (Figure 2(F1)) in the same-scale image $(200 \mathrm{~nm})$.

\subsection{Powder X-ray Diffraction Pattern (PXRD)}

Powder X-ray diffraction (PXRD) measurement was carried out to characterize the GO, Dawson-type POM, and GO-POM nanocomposite structures. As shown in Section 3.7.1, Figures S4 and S5 (see supporting information), the PXRD patterns of the $\mathrm{GO}_{\mathrm{c} 70}, \mathrm{GO}_{\mathrm{c} 72}$, $\mathrm{GO}_{\mathrm{c} 39}$, and $\mathrm{GO}_{\mathrm{c} 40}$ show diffractions at $2 \theta=11.58^{\circ}, 8.66^{\circ}, 8.91^{\circ}$, and $9.13^{\circ}$, respectively. The d-spacing increases from $0.34 \mathrm{~nm}$ of graphite spacing (002) to $0.77-1.02 \mathrm{~nm}$, which corresponds to the typical diffraction peak of the GO nanosheet (Table S2, see supporting information). The interlayer distance was calculated by Bragg's law, as shown below:

$$
\mathrm{d}=\lambda / 2 \sin (\theta)=0.154 \mathrm{~nm} / 2 \sin (\theta)
$$

where $\mathrm{d}$ is the distance between the layers of GO, $\theta$ is the diffraction angle, and $\lambda$ is the wavelength of the $X$-ray beam $(\lambda=0.154 \mathrm{~nm})$.

Although the $d$-spacing of $\mathrm{GO}_{\mathrm{c} 70}$ is shorter than those of $\mathrm{GO}_{\mathrm{c} 72}, \mathrm{GO}_{\mathrm{c} 39}$, and $\mathrm{GO}_{\mathrm{c} 40}$, it is suggested that oxygen-containing functional groups (epoxide, hydroxyl on the basal plane, and carboxyl groups on the edge of the basal plane) successfully formed in different degrees of oxidation. This is the reasonable explanation to the enhancement of the interlayer spacing of GO [39]. 


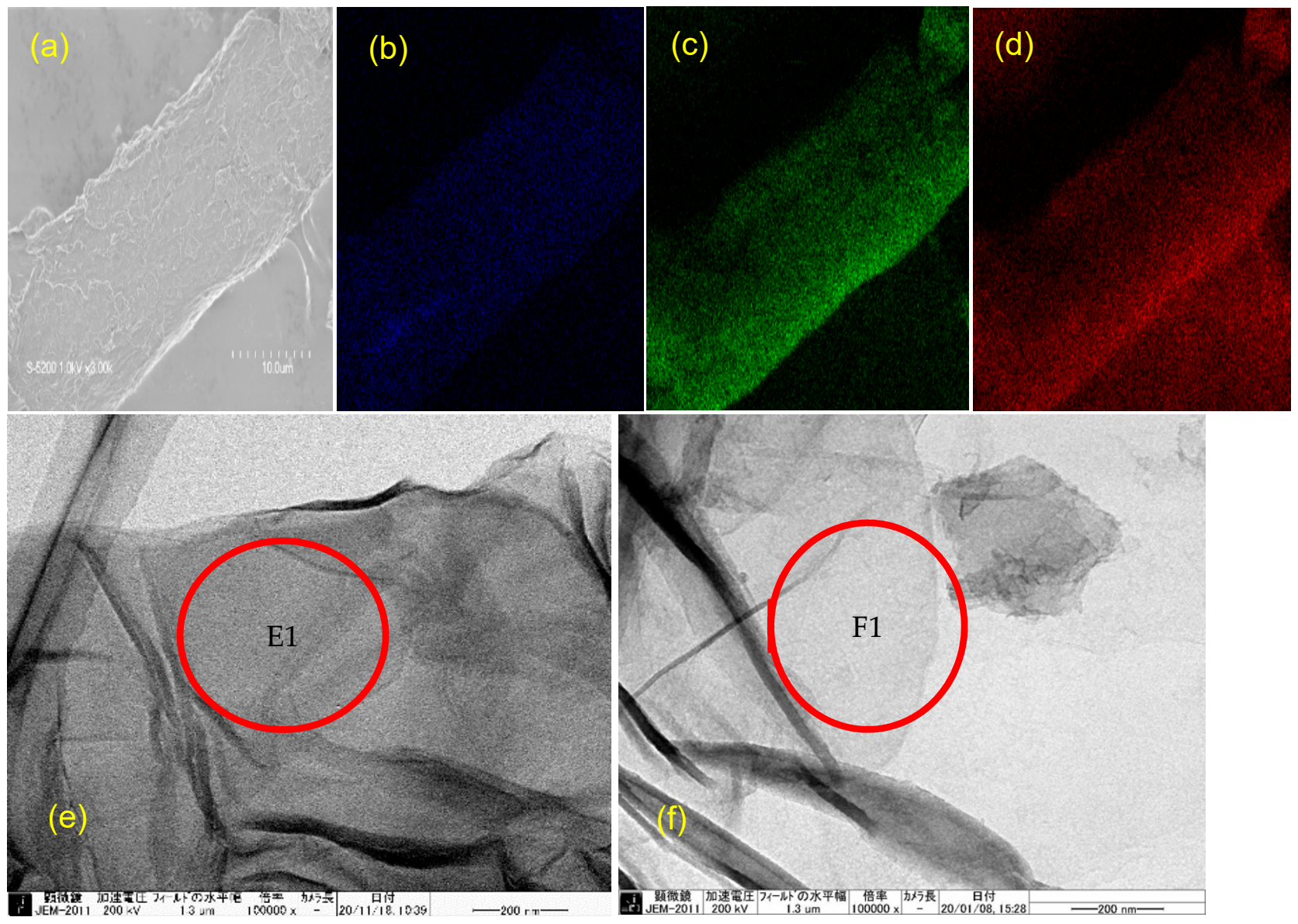

Figure 2. SEM measurement: (a) $\left[\mathrm{GO}_{70} \mathrm{POM}\right]_{41}$, its EDS map (b) Tungsten element, (c) Oxygen element, (d) Carbon K- $\alpha$ X-ray element; TEM image: (e) $\left[\mathrm{GO}_{70} \mathrm{POM}\right]_{41}$, (f) $\mathrm{GOc}_{70}$, showing the formation of (a) layer after forming the composite $\left[\mathrm{GO}_{70} \mathrm{POM}\right]_{41}$ (E1) compared with the original $\mathrm{GO}_{\mathrm{C} 70}(\mathbf{F 1})$ in the same-scale image $(200 \mathrm{~nm})$.

The diffraction peaks of all samples were slightly shifted by forming the composite (Figures S4 and S5 (see supporting information)). That is, the d-spacing decreased by forming the composite, except for $\left[\mathrm{GO}_{70} \mathrm{POM}\right]_{41}$ (Table S2, see supporting information). The result of $\left[\mathrm{GO}_{70} \mathrm{POM}\right]_{41}$ might agree with the previous work that might be assumed as a consequence of a partial intercalation of the POM species and random arrangement of the carbon layers [40]. The results except for the $\left[\mathrm{GO}_{70} \mathrm{POM}\right]_{41}$ result revealed that the $\alpha-\mathrm{K}_{6} \mathrm{P}_{2} \mathrm{~W}_{18} \mathrm{O}_{62}$ species are not embedded in between the GO sheets; however, it could be assumed that the POM species decorated on the surface of GO, as is assumed in Figure S3 (see supporting information). It is already known that the molecular size of the $\alpha$ $\mathrm{K}_{6} \mathrm{P}_{2} \mathrm{~W}_{18} \mathrm{O}_{62}$ species is larger (ca. $1.03 \mathrm{~nm} \times 1.5 \mathrm{~nm}$ ) [20] than the d-spacing of each GO sample $(0.77-1.02 \mathrm{~nm})$.

In addition, we could see in Table S2 (see supporting information) the out of plane crystallite size of GO samples. The size was calculated by using the Debye-Scherrer equation:

$$
\mathrm{D}(\mathrm{nm})=0.9 \lambda \beta^{-1}(\cos (\theta))^{-1}
$$

where $\mathrm{D}$ is the average out of plane crystallite size $(\mathrm{nm}), \lambda$ is the wavelength of the $\mathrm{X}$-ray beam, $\beta$ is the FWHM (full width at half maximum), $\theta$ is the XRD peak position.

The in-plane crystallite size of the GO samples and the average number of graphene oxide layers $(n)$ per domain were also estimated by using PXRD data. The following general formula is described in [41]:

$$
\mathrm{L}(\mathrm{nm})=1.84 \lambda / \beta \cdot \cos (\theta)
$$




$$
n=\mathrm{D} / \mathrm{d}+1=\left(0.9 \lambda \beta^{-1}(\cos (\theta))^{-1} / \mathrm{d}\right)+1
$$

where $D$ is the average out of plane crystallite size $(n m), d$ is the interlayer distance, $\lambda$ is the wavelength of the X-ray beam, $\beta$ is the FWHM (full width at half maximum), $\theta$ is the XRD peak position, and $n$ is the number of layers of the GO sample. These calculations provide crucial information regarding the average crystallite size (reflecting the enhancement or reduction of the graphitic zone and the grain boundaries or lateral defect formation) and the average number of GO layers (see Table S2, supporting information).

\subsection{Raman Spectroscopy}

Raman spectroscopy was used to characterize the GO material, and also, it provides the structural information in detail to draw its quality [42]. From the spectra, we could see the $\mathrm{D}$ bands located at $1356 \mathrm{~cm}^{-1}, 1352 \mathrm{~cm}^{-1}, 1352 \mathrm{~cm}^{-1}$, and $1347 \mathrm{~cm}^{-1}$ for $\mathrm{GO}_{\mathrm{c} 70}, \mathrm{GO}_{\mathrm{c} 72}$, $\mathrm{GO}_{\mathrm{c} 39}$, and $\mathrm{GO}_{\mathrm{c} 40}$, respectively (see Figure S9 supporting information). This indicates the extensive oxidation of graphite and extended amounts of the $\mathrm{sp}^{3}$-hybridized carbon atoms [43]. The $G$ bands located at $1586,1581,1590$, and $1590 \mathrm{~cm}^{-1}$ for $\mathrm{GO}_{\mathrm{c70}}, \mathrm{GO}_{\mathrm{c72}}, \mathrm{GO}_{\mathrm{c} 39}$, and $\mathrm{GO}_{\mathrm{c} 40}$, respectively, correspond to the $\mathrm{sp}^{2}$-hybridized carbon atoms in the hexagonal framework. The $\mathrm{G}$ band is inherently with the $2 \mathrm{D}$ band (the second-order Raman modes) that appears at $2700 \mathrm{~cm}^{-1}$. The critical thing to fully and accurately characterize the GO sample is the consideration of the second-order Raman modes [44]. The area ratio of the 2D band also has a linear correlation with the hole mobility [45]. In addition, the previous work has explained the packing mechanism of multiple layers GO (bi-, tri- layers) by STEM-ADF image simulation. It showed that the disorder of the graphene sheet and the roughness have been created by the random covalent attachment of oxygen on the top and bottom surfaces. It influences the lattice distortion and breaks the symmetry of the system [46]. Therefore, it can be predicted that the different C/O ratio of GO samples in our work is sufficient to influence the material structure of the GO-POM composite and the ability to adsorb the Cs.

As presented in Table $\mathrm{S} 1$ (see supporting information), the intensity ratio of $\mathrm{I}_{\mathrm{D}} / \mathrm{I}_{\mathrm{G}}$ of each original material $\left(\mathrm{GO}_{\mathrm{c} 70}, \mathrm{GO}_{\mathrm{c} 72}, \mathrm{GO}_{\mathrm{c} 39}\right.$, and $\left.\mathrm{GO}_{\mathrm{c} 40}\right)$ are $0.93,0.91,0.89$, and 0.88, respectively. These values are correlated with the different compositions of the $\mathrm{C} / \mathrm{O}$ ratio on each GO sample that are already discussed in the previous section. The intensity ratio $\left(\mathrm{I}_{\mathrm{D}} / \mathrm{I}_{\mathrm{G}}\right)$ tends to increase by forming a composite. Therefore, we may conclude that the anchored process of POM on the GO has affected the structure of GO. In this case, also, there was an opposite trend for $\mathrm{GO}_{\mathrm{c} 70}$.

\subsection{Cs Adsorption Performance}

\subsubsection{Adsorption Efficiency and Adsorption Capacity of GO and POM}

The Cs adsorption capacities of $\mathrm{GO}_{\mathrm{c70}}, \mathrm{GO}_{\mathrm{c7} 2}, \mathrm{GO}_{\mathrm{c} 39}$, and $\mathrm{GO}_{\mathrm{c} 40}$ and $\mathrm{POM}$ are summarized in Table 2. Those of GO-POM nanocomposites are presented in Table 3 (see Section 3.7.2). The GO samples were classified into two types according to the elemental analysis. The $\mathrm{GO}_{\mathrm{c} 70}$ and $\mathrm{GO}_{\mathrm{c} 72}$ have $70-72 \mathrm{wt} \% \mathrm{C}$ element, while $\mathrm{GO}_{\mathrm{c} 39}$ and $\mathrm{GO}_{\mathrm{c} 40}$ have $\approx 39 \mathrm{wt} \% \mathrm{C}$ element. As shown in Table 2, the result of the present work pointed out that there is not much difference in the $\mathrm{Cs}^{+}$adsorption by $\mathrm{POM}, \mathrm{GO}_{\mathrm{c} 70}, \mathrm{GO}_{\mathrm{c} 72}, \mathrm{GO}_{\mathrm{c} 39}$, and $\mathrm{GO}_{\mathrm{c} 40}$ among the samples. The role of different $\mathrm{C} / \mathrm{O}$ ratios in capturing $\mathrm{Cs}$ cannot be revealed. It is also already shown by other researchers that the C/O ratio of $\mathrm{GO}$ does not have systematic correlation with the ion exchange capacity [43]. 
Table 2. Adsorption capacity, adsorption efficiency, and adsorption condition.

\begin{tabular}{ccccc}
\hline Materials & $\begin{array}{c}\text { Adsorption } \\
\text { Efficiency }\end{array}$ & $\begin{array}{c}\text { Adsorption } \\
\text { Capacity }\end{array}$ & Stirring & $\begin{array}{c}\text { Sonification } \\
\text { Time }\end{array}$ \\
\cline { 2 - 5 } & $\mathbf{( \% )}$ & $\mathbf{( m m o l / g )}$ & Time & (minute) \\
\hline $\mathrm{POM}-\mathrm{Cs}$ & 58.3 & 32.8 & $24 \mathrm{~h}$ & 5 \\
\hline $\mathrm{GO}_{\mathrm{c} 70-\mathrm{Cs}}$ & 58.8 & 33.1 & $24 \mathrm{~h}$ & 5 \\
\hline $\mathrm{GO}_{\mathrm{c} 72-\mathrm{Cs}}$ & 56.8 & 31.9 & $24 \mathrm{~h}$ & 5 \\
\hline $\mathrm{GO}_{\mathrm{c} 39}-\mathrm{Cs}$ & 61.3 & 34.5 & $24 \mathrm{~h}$ & 5 \\
\hline $\mathrm{GO}_{\mathrm{c} 40}-\mathrm{Cs}$ & 56.3 & 31.7 & $24 \mathrm{~h}$ & 5 \\
\hline
\end{tabular}

Table 3. Adsorption capacity, adsorption efficiency, and adsorption condition.

\begin{tabular}{ccccccc}
\hline \multirow{2}{*}{ Materials } & Composition & $\begin{array}{c}\text { Concentration } \\
\text { Ratio }\end{array}$ & Adsorption & $\begin{array}{c}\text { Adsorption } \\
\text { Capacity }\end{array}$ & Stirring & $\begin{array}{c}\text { Sonification } \\
\text { Time }\end{array}$ \\
\cline { 3 - 7 } & & GO:POM & Efficiency $(\%)$ & $(\mathbf{m m o l} / \mathbf{g})$ & Time & (minute) \\
\hline$\left[\mathrm{GO}_{70} \mathrm{POM}\right]_{18}$ & $\left(\mathrm{GO}_{\mathrm{c} 70} / \mathrm{POM}\right)$ & $1: 08$ & 84 & 47.3 & $24 \mathrm{~h}$ & 5 \\
\hline$\left[\mathrm{GO}_{70} \mathrm{POM}\right]_{41}$ & $\left(\mathrm{GO}_{\mathrm{c} 70} / \mathrm{POM}\right)$ & $4: 01$ & 62.7 & 35.3 & $24 \mathrm{~h}$ & 5 \\
\hline$\left[\mathrm{GO}_{72} \mathrm{POM}\right]_{18}$ & $\left(\mathrm{GO}_{\mathrm{c} 72} / \mathrm{POM}\right)$ & $1: 08$ & 75.4 & 42.4 & $24 \mathrm{~h}$ & 5 \\
\hline$\left[\mathrm{GO}_{72} \mathrm{POM}\right]_{41}$ & $\left(\mathrm{GO}_{\mathrm{c} 72} / \mathrm{POM}\right)$ & $4: 01$ & 78.7 & 44.3 & $24 \mathrm{~h}$ & 5 \\
\hline$\left[\mathrm{GO}_{39} \mathrm{POM}\right]_{18}$ & $\left(\mathrm{GO}_{\mathrm{c} 39} / \mathrm{POM}\right)$ & $1: 08$ & 72.7 & 40.9 & $24 \mathrm{~h}$ & 5 \\
\hline$\left[\mathrm{GO}_{39} \mathrm{POM}\right]_{41}$ & $\left(\mathrm{GO}_{\mathrm{c} 39} / \mathrm{POM}\right)$ & $4: 01$ & 81.7 & 45.9 & $24 \mathrm{~h}$ & 5 \\
\hline$\left[\mathrm{GO}_{40} \mathrm{POM}\right]_{18}$ & $\left(\mathrm{GO}_{\mathrm{c} 40} / \mathrm{POM}\right)$ & $1: 08$ & 70.7 & 39.8 & $24 \mathrm{~h}$ & 5 \\
\hline$\left[\mathrm{GO}_{40} \mathrm{POM}\right]_{41}$ & $\left(\mathrm{GO}_{\mathrm{c} 40} / \mathrm{POM}\right)$ & $4: 01$ & 73.5 & 41.3 & $24 \mathrm{~h}$ & 5 \\
\hline
\end{tabular}

Furthermore, in this work, the interaction between $\mathrm{GO}_{c 70}$ and the Cs cation occurred immediately less than one minute after the stirring process (see Figures S14 and S15, supporting information). A brown milky coagulation was formed. The same behavior was observed between $\mathrm{GO}_{\mathrm{c} 72}$ and $\mathrm{Cs}$; however, there was a difference for $\mathrm{GO}_{\mathrm{c} 39}$ : the brown milky coagulation was formed in a small quantity, and the milky coagulation was not formed for $\mathrm{GO}_{\mathrm{c} 40}$. The difference might be related to the variance in $\mathrm{C} / \mathrm{O}$ ratio between $\mathrm{GO}_{\mathrm{c70}}, \mathrm{GO}_{\mathrm{c72}}$, and $\mathrm{GO}_{\mathrm{c} 39}, \mathrm{GO}_{\mathrm{c} 40}$. Moreover, it was explained that by using a surface functional group, the $\mathrm{GO}$ can attract the Cs cation by forming inner-sphere complexes [47]. The metal complexing in the oxidized GO strongly encourages the aggregation behavior and can be quantified by the critical coagulation concentrations (CCC) [48]. TEM measurement shows that there are many $\mathrm{Cs}$ clusters in the surface of $\mathrm{GO}_{\mathrm{c} 70}$ (see Figure 3c). Especially for this phenomenon, we also considered that the Cs cluster may include Al impurity (see Figure 3d). It might come from laboratory glass material, as reported by other work [31]. The black spots also can be seen in the $\left[\mathrm{GO}_{40} \mathrm{POM}\right]_{41}$, which consists of $\mathrm{GO}_{\mathrm{c} 40} / \mathrm{POM}$. However, the black spots are not uniformly found all over the surface area. It is theoretically explained that most of the surface reactions eventuate only on the active site and do not happen uniformly over the surface area [49]. As proposed by other work, the edge site of graphene (carbene- and carbyne-type carbon atoms) has a significant role for adsorption on the surface of $\mathrm{sp}^{2}$-hybridized carbon [50]. It is also confirmed by previous study that some ions or molecules dissolved in water have a good penetration rate through the graphene nanocapillaries until the physical size of the ions or molecules exceeds the critical one [51]. A highly oxidized domain and the hydrophobic domain in GO have different roles. The highly oxidized domain would be responsible for rapid water transport in the interlayer of GO, while the hydrophobic domain would serve a network of capillaries [43]. Another researcher also considered the polarizability of graphene in order 
to estimate the orientation of interfacial water [52], and the interfacial water can be used to observe the surface adsorption behavior [53]. Based on these analyses, it can be assumed that the interfacial water may support the Cs interaction with GO.
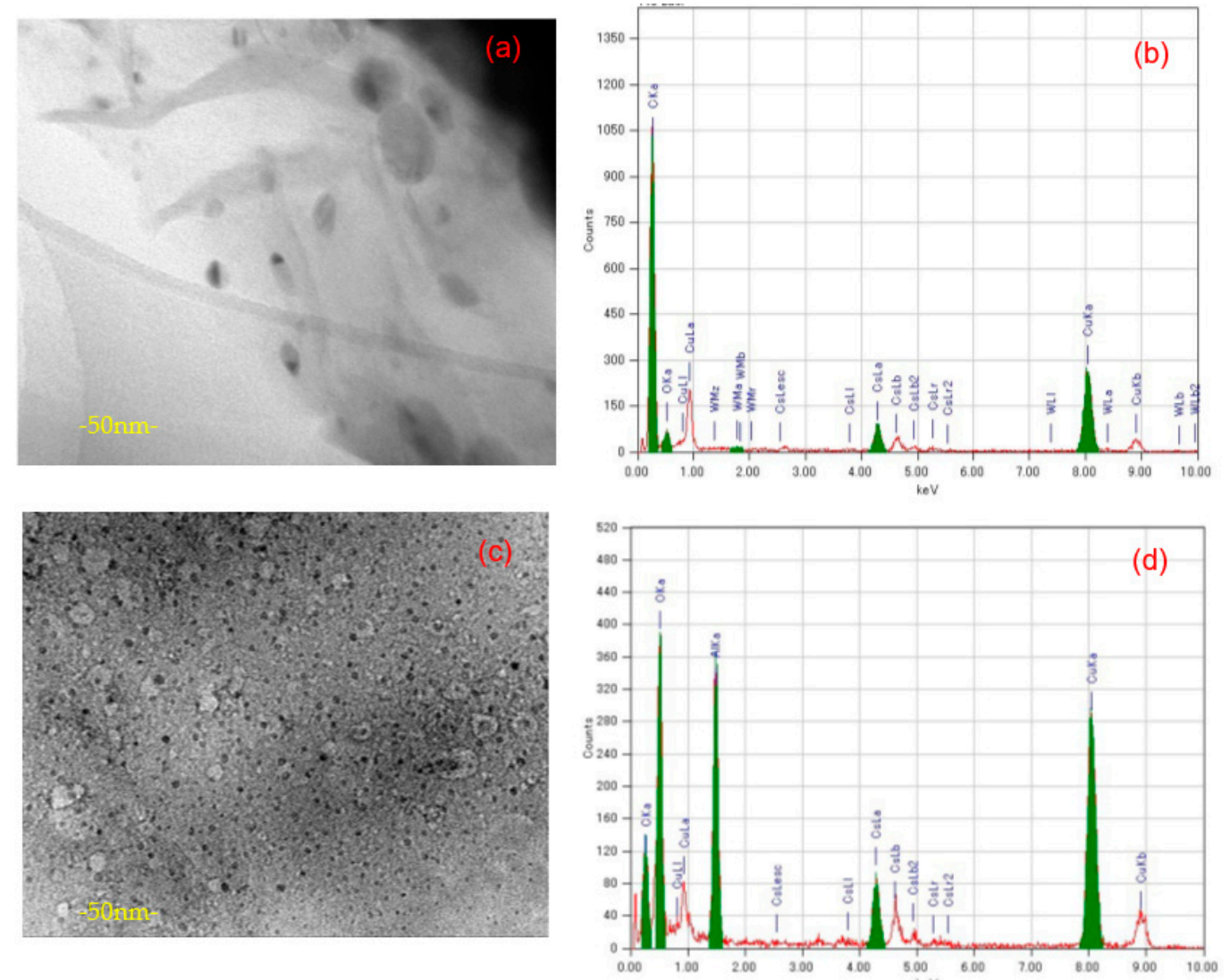

Figure 3. TEM image: (a) $\left[\mathrm{GO}_{40} \mathrm{POM}\right]_{41}$ after $\mathrm{Cs}$ adsorption, small black spots are identified (scale: $50 \mathrm{~nm}$ ), (b) Elemental analysis of (a), (c) $\mathrm{GO}_{\mathrm{c} 70}$ after Cs adsorption, many small Cs clusters are seen (scale: $50 \mathrm{~nm}),(\mathrm{d})$ Elemental analysis of $(\mathbf{c})$.

The other important evidence of Cs adsorption is also visible in PXRD measurement. The sharp and intense diffraction peaks were reduced by introducing Cs (Figures 4 and S5 (see supporting information)). The broad diffraction of $\mathrm{GO}_{\mathrm{c} 70}, \mathrm{GO}_{\mathrm{c} 72}, \mathrm{GO}_{\mathrm{c} 39}$, and $\mathrm{GO}_{\mathrm{c} 40}$ showed the non-uniform surface complexation with the Cs cation. PXRD and TEM show the formation of the Cs cluster. This might correspond to the origin of GO acidity, which contributes to the high cation exchange capacity (CEC). The GO acidity is made by oxygen functional groups, and the main moieties responsible for the acidic properties are carboxyl groups [43]. Moreover, according to the result by Dimiev et al. (2012), there is one acidic site for every six to eight carbon atoms; i.e., $100 \mathrm{~g}$ of GO sample contains 500-800 mmol of active acidic sites [54]. The adsorption capacity of the present GOs ( $\approx 3200 \mathrm{mmol} / 100 \mathrm{~g})$ (Table 2) is larger than the concentration of the active acidic site. This is due to the formation of a Cs cluster. It is also generally accepted that the basicity and the size of the molecule to be adsorbed are a significant aspect in the adsorption process [55,56]. In this work, the $\mathrm{pH}$ of the solution is around 5-6 when the Cs contacts the GO-POM composite or GO only. Some previous researchers have proved that the $\mathrm{pH}$ condition in GO samples influences the adsorption capacity. It can be explained that at $\mathrm{pH}$ above $3.9\left(\mathrm{pH}_{\mathrm{pzc}}\right)$, the surface area of GO is partially negatively charged and the electrostatic attractions between cations and $\mathrm{GO}$ are stronger because of deprotonation reaction [57]. It is also caused by the higher availability of active sites on the GO sheets [58]. 

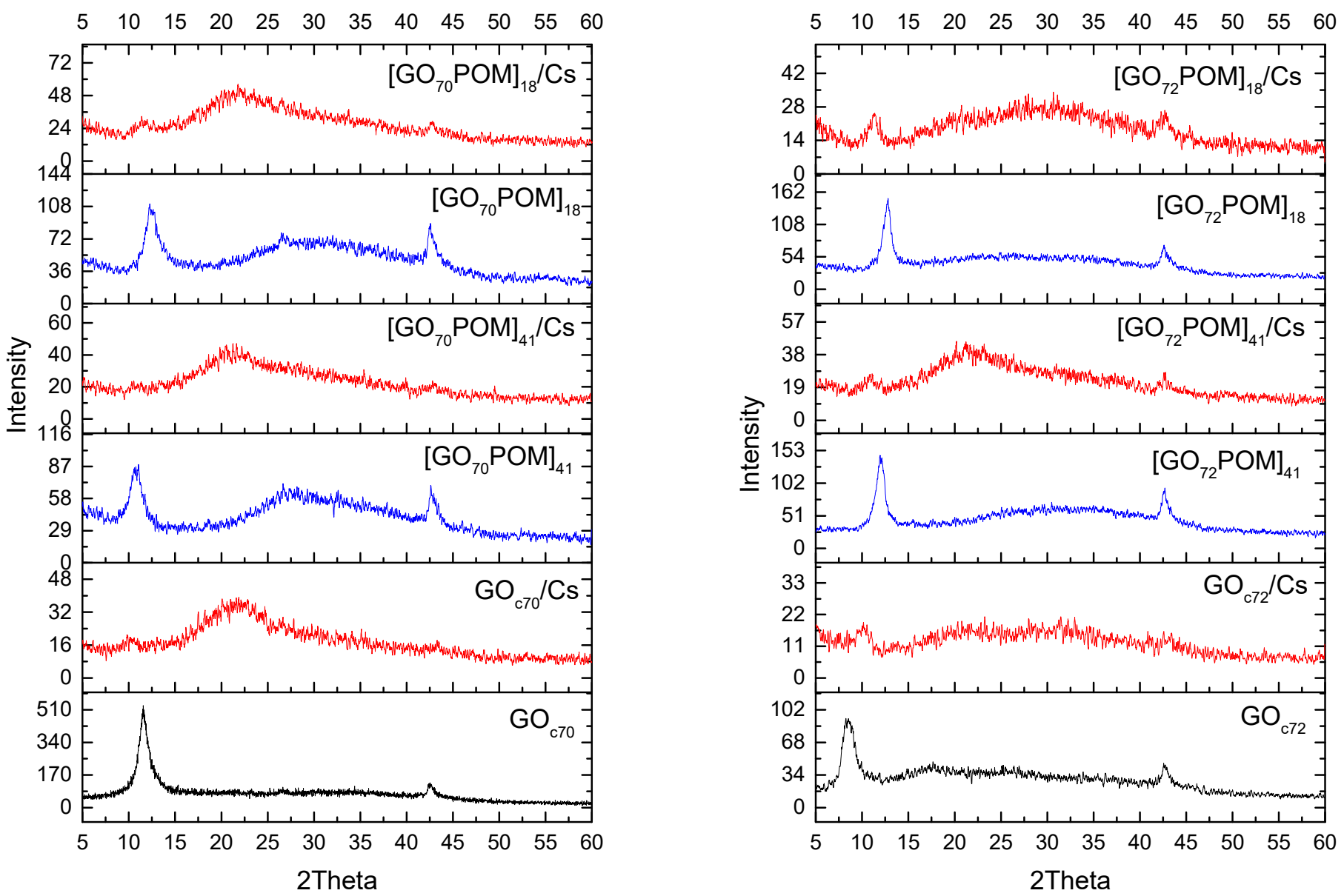

Figure 4. PXRD patterns of $\mathrm{GO}_{\mathrm{c} 70}, \mathrm{GO}_{\mathrm{c} 72}$, and their GO-POM nanocomposite before and after Cs adsorption.

As discussed above, these data have a good correlation with the information that is observed in Raman spectra. Based on Raman analysis (Figures 5 and S9-S12 (see supporting information)), it was found that the change in spectrum by Cs adsorption was similar for both the GO-only samples and composite samples. It can be seen that the second-order peaks have changed after Cs adsorption. In previous studies, it was strengthened that the second-order peak indicates that the crystallite size has changed. This indicator showed that the spectrum broadens consistently with decreasing the domain size [59]. Therefore, during the chemical processing (Cs adsorption), the significant structural change of the carbon framework occurred. In addition, based on the sample experiment using $\left[\mathrm{GO}_{39} \mathrm{POM}\right]_{41}$, there is a slight shift in the D band from $1347 \mathrm{~cm}^{-1}$ before Cs adsorption to $1352 \mathrm{~cm}^{-1}$ after $\mathrm{Cs}$ adsorption. The same shift also occurred in the other samples, $\left[\mathrm{GO}_{70} \mathrm{POM}\right]_{18}$ and $\left[\mathrm{GO}_{70} \mathrm{POM}\right]_{41}$ (Figure $\mathrm{S} 9$, see supporting information). It might be caused by the interaction of oxygen functional groups and the hole defect in the GO sheets with Cs cation [58]. Thus, the change that the crystal structure after Cs adsorption has altered by amorphization could be confirmed. 


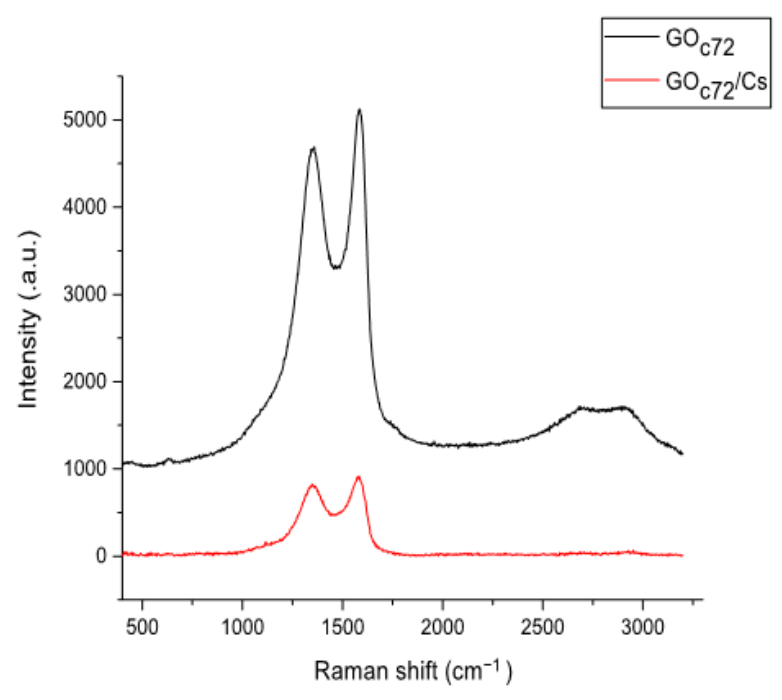

(a)

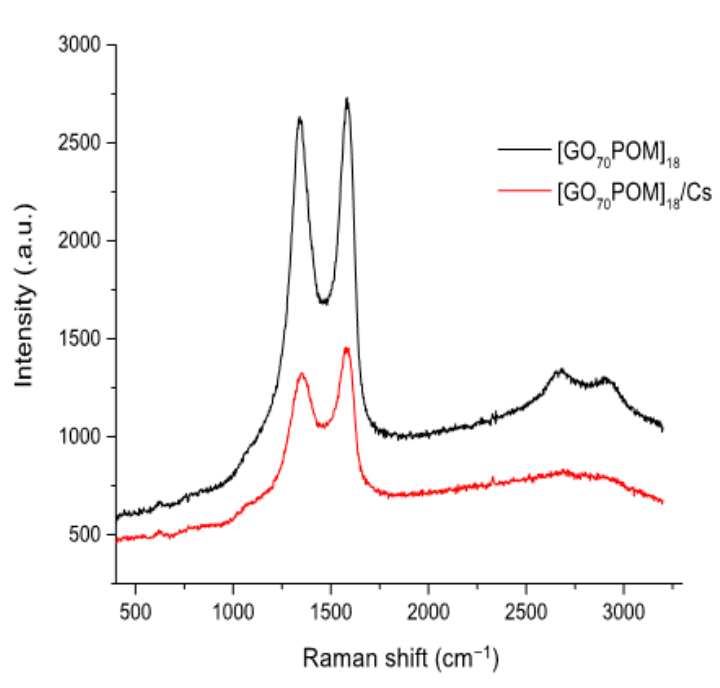

(b)

Figure 5. Raman spectra before and after $\mathrm{Cs}$ adsorption for (a) $\mathrm{GO}_{\mathrm{c72}}(\mathbf{b})\left[\mathrm{GO}_{70} \mathrm{POM}\right]_{18}$.

\subsubsection{Adsorption Efficiency and Adsorption Capacity of GO-POM Nanocomposite}

Table 3 shows the result of Cs adsorption by using the GO-POM nanocomposite. The GO-POM nanocomposite (Table 3 ) increased the Cs adsorption capacity effectively compared to the adsorption capacity of the original material (Table 2). The change range is around $6.7 \%$ to $42.9 \%$. This result is consistent with the previous finding that signified the characteristic of surface area, showing an important role of POM species with carbon materials [60,61]. As a consequence, the $\mathrm{Cs}^{+}$adsorption becomes high. We compared the average increment of $\mathrm{Cs}$ adsorption of the composite material between $\mathrm{GO}$ having $70-72 \mathrm{wt} \% \mathrm{C}$ element and GO having 39-40 wt \% C element. The functional groups of GO provide a binding point for chemical modification [25]. It is seen in Figure 6 that there is no significant difference between GO having 70-72 wt \% C element and GO having $39-40$ wt \% C element.

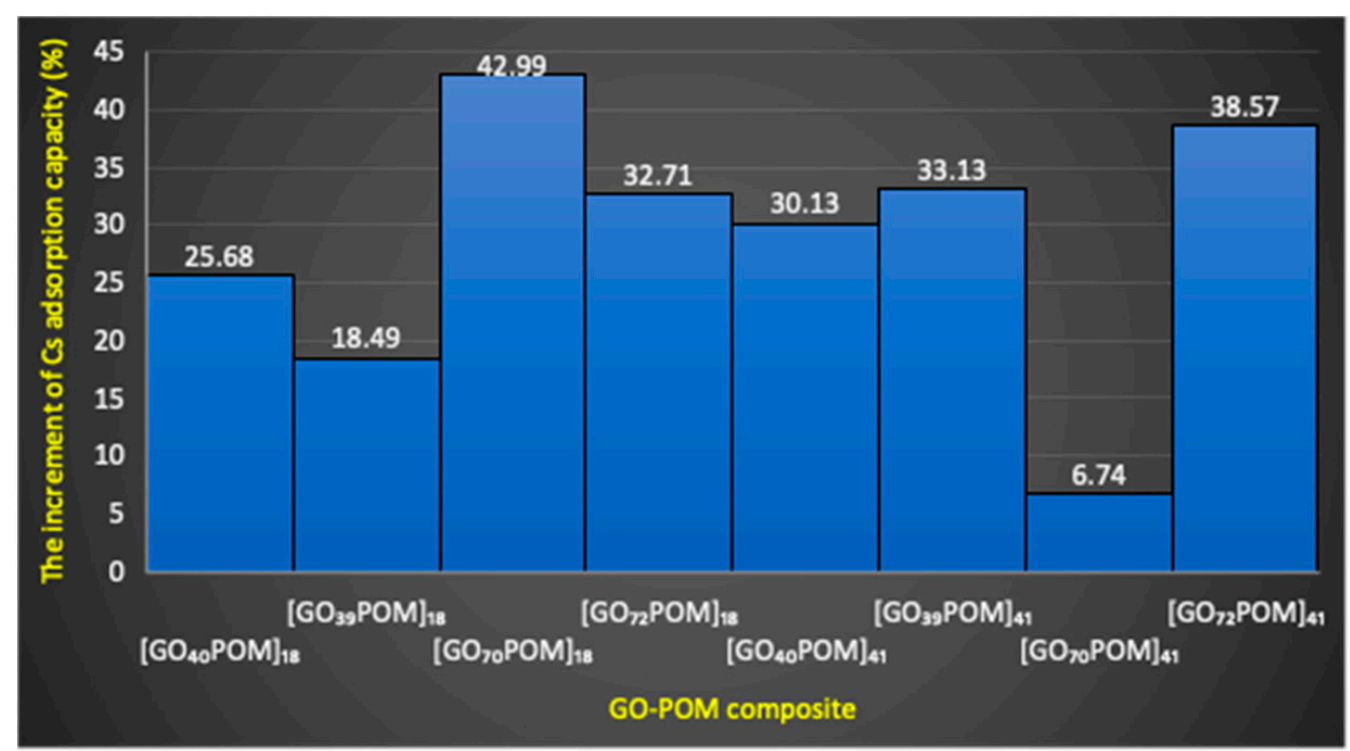

Figure 6. The increment of Cs adsorption capacity (\%) calculated by using the ratio before and after forming a composite in each GO sample. 
We compared the average increment of Cs adsorption of the composite material between the concentration ratio $1: 8$ and concentration ratio $4: 1$, but we could not find the significant difference. In principle, the adsorption behavior of the GO-POM nanocomposite might be influenced by the significant role of GO as the electron acceptor and Dawsontype POM as the electron donor that led to enhance the attraction between $\mathrm{Cs}^{+}$and the composite [62]. The other phenomena authenticated by another researcher confirmed that the interaction between POMs and GO can provide more mobile protons and flexible pathways [63]. In addition, Wang's group reported that the surface charges of GO modified by functional groups $\left(\mathrm{GO}-\mathrm{COOH}, \mathrm{GO}-\mathrm{NH}_{2}, \mathrm{GO}-\mathrm{OCH}_{3}\right)$ can be used to modulate the charge transport [64]. Therefore, the presence of Dawson-type POM in the GO system enhanced the negative charge of the GO part in the composite and provided a good adsorption of $\mathrm{Cs}^{+}$ ion (Figure S3, see supporting information). The interaction of $\mathrm{Cs}^{+}$ion with Dawson-type POM was an ion-pair complex [65]. The anion surface of Dawson-type POM is electron rich and has a strong interaction with $\mathrm{Cs}^{+}$. Therefore, the introduction of Dawson-type POM in our adsorbent system was important to enhance the adsorption of the $\mathrm{Cs}^{+}$ion. However, further investigation is still needed to find out the mechanism that occurred behind the phenomenon.

It is also reported that the mechanism of cation-GO interaction in the adsorption behavior should be considered together with aggregation process [66]. In the present study, Figure 7a,b exhibited that the aggregation occurred after Cs adsorption by using the GOPOM nanocomposite. The results demonstrated that the composite samples immediately coagulate after $\mathrm{Cs}$ adsorption except for $\left[\mathrm{GO}_{70} \mathrm{POM}\right]_{41}$, which still forms a stable solution after one hour keeping at ambient temperature (see Figure S13, supporting information). We predicted that a small granule of Cs was formed, and there was a crinkled GO sheets coating around it (see Figure S16, supporting information). It can be signified that a stronger bond was formed. It might be predicted that there is a different composition of oxidative debris (OD) component among the GO samples. As a previous study explained, the OD of GO has a significant role in the origin of GO acidity [67]. This is already discussed in the previous section (Section 3.7.1 regarding the contribution of GO acidity to the cation exchange capacity). However, further investigation is still needed to prove it and to obtain strong evidence. Unfortunately, the elemental analysis of Figure S16 (supporting information) was not conducted. Regarding this phenomenon, it can be assumed that there are two important factors that might contribute to the aggregation behavior. First, the size of the GO and composite sample matter. As presented in Table S2, the size of each sample is diverse. The range of values is around 4.3 to $34.78 \mathrm{~nm}$. A previous study showed that the size of GO (nano GO, colloid GO, micron GO) can strongly influence the aggregation behavior [68]. Second, the other factor is the degree of acidity. It is strongly related with the functionalities of the GO sample. It was explained in an earlier section in this work that there are two types of GO samples, which have different $\mathrm{C} / \mathrm{O}$ compositions. Evidence was shown by the previous study that the GO (single or multilayers) coagulates in highly acidic conditions because of losing their surface charge [54]. It is also correlated well with other work that identified the effect of cations on aggregation [47]. Moreover, it was strengthened in the previous theoretical analysis that considered the important role of $\mathrm{H}_{2} \mathrm{O}$ as a dipole molecule involving cation $-\pi$ interaction. Therefore, the electrostatic interaction would be significantly influenced $[69,70]$. As calculated in the previous studies, the value of the internuclear distances $\mathrm{d}_{\text {ion-water }}$ of $\mathrm{Cs}^{+}$is $0.315 \mathrm{~nm}$ [71]. Therefore, the interaction of $\mathrm{Cs}^{+}$with the GO-POM nanocomposite becomes easier to diffuse through the interlayer distance of the GO-POM nanocomposite, which has a d-spacing around 0.69-0.81 $\mathrm{nm}$ and 0.77-1.02 nm for the GO sample (see Figure S11, supporting information). 

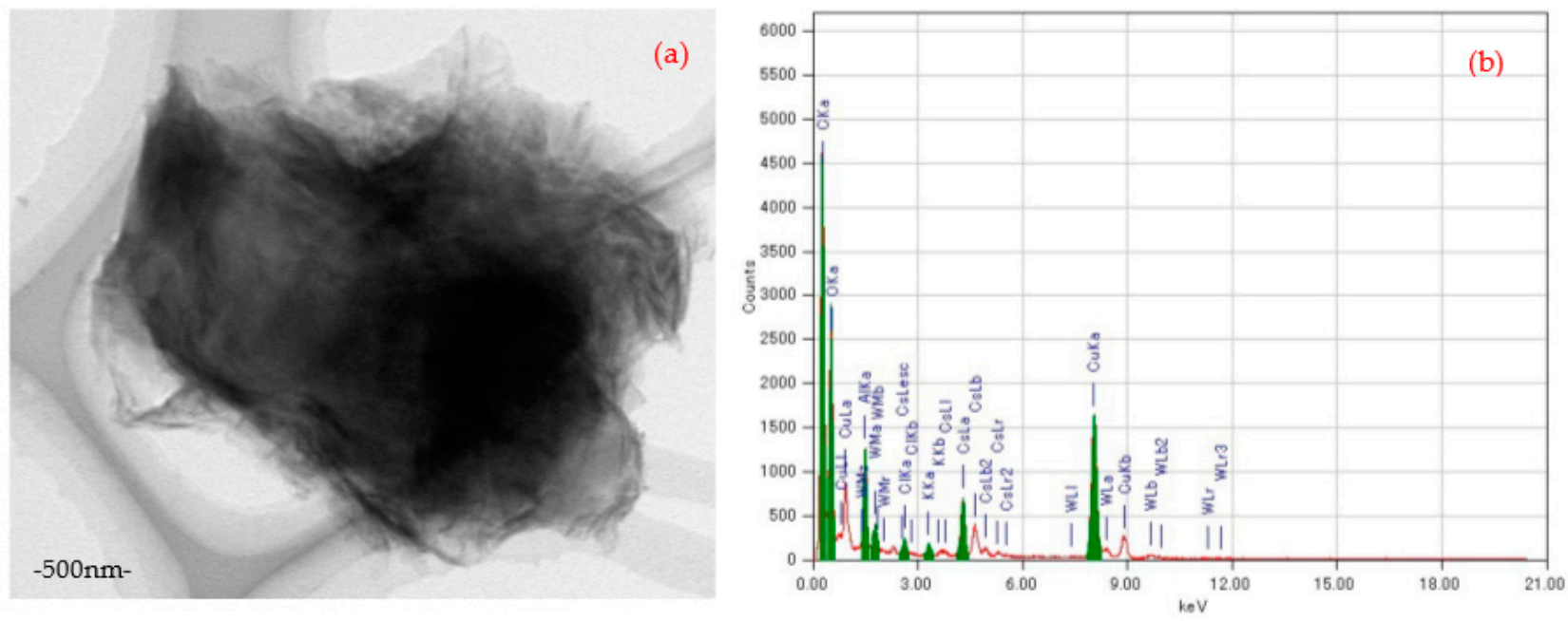

Figure 7. TEM image of $\left[\mathrm{GO}_{70} \mathrm{POM}\right]_{18} / \mathrm{Cs}$ : (a) Aggregation after Cs adsorption, (b) Elemental analysis of (a).

By FTIR spectra, specific changes are marked at $1150-1350 \mathrm{~cm}^{-1}$ after Cs adsorption in all GO-POM nanocomposites. Especially for composites that consist of $\approx 39 \mathrm{wt} \% \mathrm{C}$ element, the IR spectrum shows more significant changes (see Figures $8 \mathrm{e}-\mathrm{h}$ and S7A in the supporting information), whereas for the composites that consist of 70-72 wt \% C element, the peak shifts are not so significant, thus making analysis quite difficult (see Figures $8 \mathrm{a}-\mathrm{d}$ and S7B in the supporting information). A similar tendency also occurred in all GO samples after Cs adsorption (see Figure S6 in supporting information). This result indicates that there is a change in the interlayer chemistry of the sample that influences the defect (hole) formation and functional group formation. It might be caused by the interaction between the GO functional group (including carboxyl, phenol, multi-group ether) and the Cs cation [58]. As explained by another researcher, the $\mathrm{pH}$-driven reversible epoxide formation in GO (epoxy opening/closing reactions) should be considered as an important part of the reactivity and properties of GO [72]. The tendency is observed that the interlayer distance after $\mathrm{Cs}$ adsorption in all nanocomposite samples were expanded, even though the increment was not so high (see Table S2, supporting information). For example, in the $\left[\mathrm{GO}_{40} \mathrm{POM}\right]_{18},\left[\mathrm{GO}_{40} \mathrm{POM}\right]_{41},\left[\mathrm{GO}_{39} \mathrm{POM}\right]_{18}$, and $\left[\mathrm{GO}_{39} \mathrm{POM}\right]_{41}$ composites, the interlayer distances were changed from 7.6 to $8.3 \mathrm{~A}, 7.6$ to $7.8 \mathrm{~A}, 7.4$ to $8.1 \mathrm{~A}$, and 7.4 to $7.9 \mathrm{~A}$, respectively. It also happened in the $\left[\mathrm{GO}_{70} \mathrm{POM}\right]_{18},\left[\mathrm{GO}_{70} \mathrm{POM}\right]_{41},\left[\mathrm{GO}_{72} \mathrm{POM}\right]_{41}$, and $\left[\mathrm{GO}_{39} \mathrm{POM}\right]_{18}$ composites, where the d-spacing was expanded from 7.2 to $7.9 \mathrm{~A}, 8.1$ to $8.6 \mathrm{~A}, 7.3$ to $7.9 \mathrm{~A}$, and 6.9 to $7.7 \mathrm{~A}$, respectively. In addition, the other study confirmed that the $\mathrm{CO}_{2}$ gas is trapped within the multilayers of GO (marked at $2357-2359 \mathrm{~cm}^{-1}$ ). Intentionally, they verified that the intercalated water has an essential role for accelerating the reaction by some specific mechanism [73].

Another work also confirmed that the functional group of GO can act as a ligand to replace the water molecule from the metal cations in the first coordination sphere. Previous work verified that the relaxation time by using the NMR relaxation method can be considered as an essential variable for identifying the metal complexing mechanism of GO in different charge, size, and electron configuration of the metal as a function of $\mathrm{pH}$ and GO concentration [74]. It was also confirmed by another study that the presence of wrinkle-like water tunnels has a strong relation with the water adsorption ability of GO [75]. 

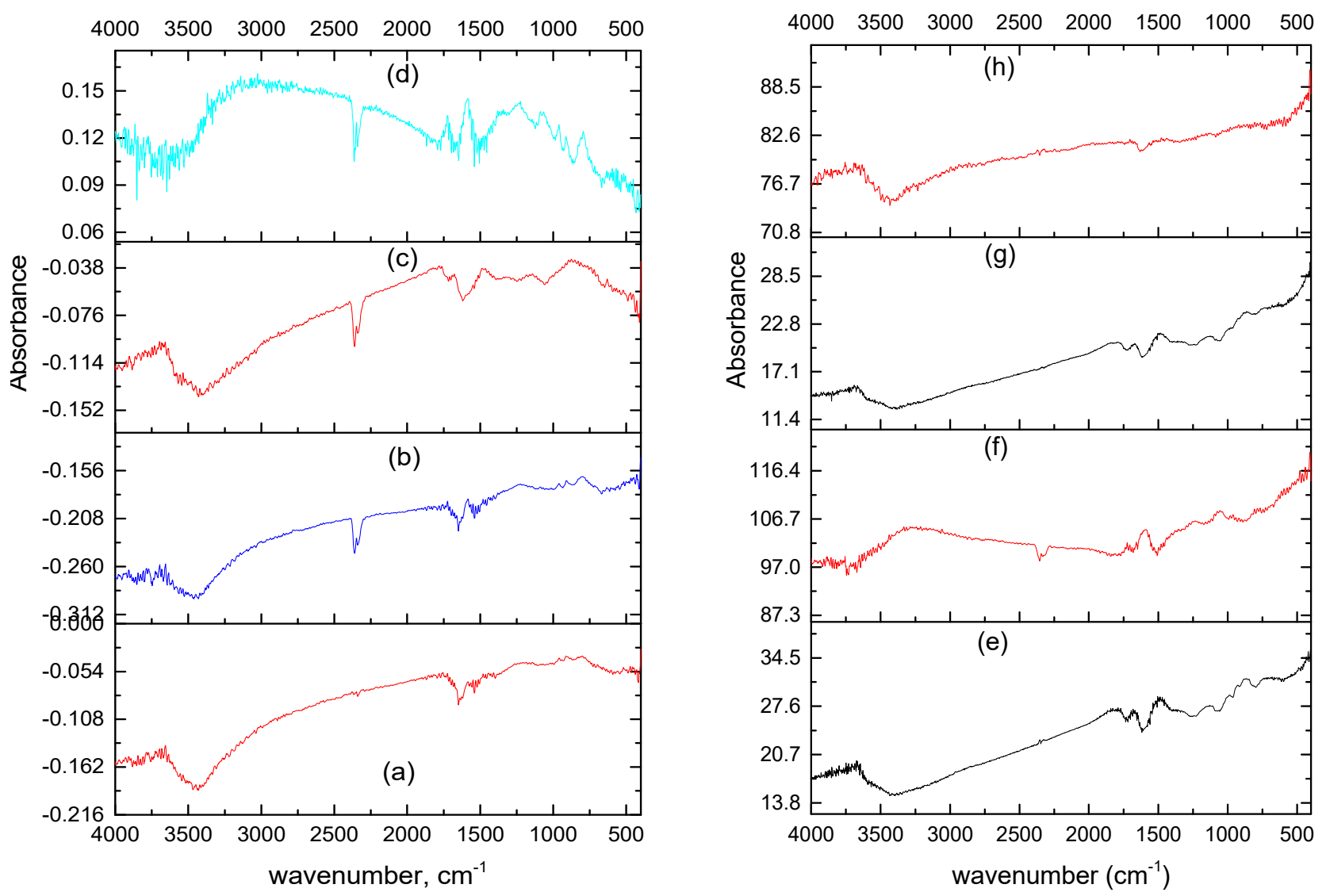

Figure 8. IR spectra for (a) $\left[\mathrm{GO}_{70} \mathrm{POM}\right]_{18},(\mathbf{b})\left[\mathrm{GO}_{70} \mathrm{POM}\right]_{18}$ after Cs adsorption, (c) $\left[\mathrm{GO}_{70} \mathrm{POM}\right]_{41},(\mathbf{d})\left[\mathrm{GO}_{70} \mathrm{POM}\right]_{41}$ after Cs adsorption, (e) $\left[\mathrm{GO}_{40} \mathrm{POM}\right]_{18},(\mathbf{f})\left[\mathrm{GO}_{40} \mathrm{POM}\right]_{18}$ after $\mathrm{Cs}$ adsorption, (g) $\left[\mathrm{GO}_{40} \mathrm{POM}\right]_{41}$, and (h) $\left[\mathrm{GO}{ }_{40} \mathrm{POM}\right]_{18}$ after Cs adsorption.

Deeper investigation into carbon species in each composite sample was performed. This is shown in Table 4, where the graphitic zone can be calculated by using the integrated intensity of graphitic $(2 \theta=26.6)$ and oxidized peaks $(2 \theta=8.66-15)$ in the PXRD pattern. The amount of graphitic zone ( $G \%$, unoxidized region) was calculated using Equation (7), as follows:

$$
G \%=\frac{\text { Igraphite }}{\text { Igraphite }+ \text { Ioxidized }} \times 100
$$

where $I_{\text {graphite }}$ and $I_{\text {oxidized }}$ are the intensities of the graphitic and oxidized diffraction peaks of GO in the PXRD pattern, respectively [76].

As presented in Table 4 , the diversification of $\mathrm{sp}^{2} / \mathrm{sp}^{3}$ carbon clusters on each sample has been produced. This variance among the samples indicates that there is a difference in the degree of oxidation. However, a peculiar phenomenon was seen in the $\mathrm{GO}_{\mathrm{c} 70}$ sample. The data in Table 4 show that the percentage of the oxidized zone of $\mathrm{GO}_{\mathrm{c} 70}$ is higher compared to those of $\mathrm{GO}_{\mathrm{c} 72}, \mathrm{GO}_{\mathrm{c} 39}$, and $\mathrm{GO}_{\mathrm{c} 40}$. The ratio of the oxidized zone is not much different for $\mathrm{GO}_{\mathrm{c} 72}, \mathrm{GO}_{\mathrm{c} 39}$, and $\mathrm{GO}_{\mathrm{c} 40}$. The $\mathrm{GO}_{\mathrm{c} 70}$ shows the shorter interlayer distance than $\mathrm{GO}_{\mathrm{c} 72}, \mathrm{GO}_{\mathrm{c} 39}$, and $\mathrm{GO}_{\mathrm{c} 40}$. This may cause the peculiarity of $\mathrm{GO}_{\mathrm{c} 70}$. However, the peculiarity of $\mathrm{GO}_{\mathrm{c} 70}$ is still under study. According to the literature, the ratio of the oxidized zone does not have a linear correlation with the oxidation ratio [77]. The unusual characteristic of $\mathrm{GO}_{\mathrm{c} 70}$ also has a direct effect on the composite material produced by using $\mathrm{GO}_{\mathrm{c} 70}$ (as provided at the beginning of Section 3.7.2). Further investigation is needed to obtain more understanding of the dependence of these factors. A recent study revealed that the ratio $\mathrm{C} / \mathrm{O}$ has a big influence on the physical properties because of the change of the surface speciation [78]. Another investigation also confirmed a strong correlation 
between the content of Lewis acid sites (via basal plane epoxide) and the Bronsted acidic carboxylic group in the GO sample with a strong acidity and high oxidation degree [79].

Table 4. The $\mathrm{sp}^{2} / \mathrm{sp}^{3}$ carbon cluster on each composite surface.

\begin{tabular}{cccc}
\hline Material & Composition & $\begin{array}{c}\text { Graphitic Zone } \\
(\mathbf{G} \%)\end{array}$ & Oxidized Zone (\%) \\
\hline $\mathrm{GO}_{\mathrm{c} 70}$ & - & 69.7 & 30.3 \\
\hline $\mathrm{GO}_{\mathrm{c} 72}$ & - & 75.4 & 24.6 \\
\hline $\mathrm{GO}_{\mathrm{c} 39}$ & - & 74.9 & 25.1 \\
\hline $\mathrm{GO}_{\mathrm{c} 40}$ & - & 74.5 & 25.5 \\
\hline$\left[\mathrm{GO}_{70} \mathrm{POM}\right]_{18}$ & $\mathrm{GO}_{\mathrm{c} 70} / \mathrm{POM}, 1: 8$ & 68.4 & 31.6 \\
\hline$\left[\mathrm{GO}_{70} \mathrm{POM}\right]_{41}$ & $\mathrm{GO}_{\mathrm{c} 70} / \mathrm{POM}, 4: 1$ & 71.4 & 28.6 \\
\hline$\left[\mathrm{GO}_{72} \mathrm{POM}\right]_{18}$ & $\mathrm{GO}_{\mathrm{c} 72} / \mathrm{POM}, 1: 8$ & 67.5 & 32.5 \\
\hline$\left[\mathrm{GO}_{72} \mathrm{POM}\right]_{41}$ & $\mathrm{GO}_{\mathrm{c} 72} / \mathrm{POM}, 4: 1$ & 69.0 & 30.9 \\
\hline$\left[\mathrm{GO}_{39} \mathrm{POM}\right]_{18}$ & $\mathrm{GO}_{\mathrm{c} 39} / \mathrm{POM}, 1: 8$ & 69.0 & 31.0 \\
\hline$\left[\mathrm{GO}_{39} \mathrm{POM}\right]_{41}$ & $\mathrm{GO}_{\mathrm{c} 39} / \mathrm{POM}, 4: 1$ & 69.3 & 30.7 \\
\hline$\left[\mathrm{GO}_{40} \mathrm{POM}\right]_{18}$ & $\mathrm{GO}_{\mathrm{c} 40} / \mathrm{POM}, 1: 8$ & 69.1 & 30.0 \\
\hline$\left[\mathrm{GO}_{40} \mathrm{POM}\right]_{41}$ & $\mathrm{GO}_{\mathrm{c} 40} / \mathrm{POM}, 4: 1$ & 69.5 & 30.5 \\
\hline & & &
\end{tabular}

Furthermore, the data show that the oxidized zone $\left(\mathrm{sp}^{2} / \mathrm{sp}^{3}\right.$ hybrid carbon) of each composite sample was enlarged compared to the corresponding original GO. Only $\left[\mathrm{GO}_{70} \mathrm{POM}\right]_{41}$, which consists of $\mathrm{GO}_{\mathrm{c} 70 /} \mathrm{POM}$ with a concentration ratio of $4: 1$, was decreased. It correlated well with the in-plane crystallite size of each composite material that expanded (see Table S2, supporting information). Particularly, the GO-POM nanocomposite with a concentration ratio of 4:1 shows an in-plane crystallite size larger than the GO-POM nanocomposite with a concentration ratio of 1:8. It could be assumed that there is an electron transfer from POM species to GO $[80,81]$. Another researcher also confirmed that the surface area of the GO-POM composite was improved five times due to the covalent bond between the POM species and GO [38]. In general, the enhancement of adsorption capacity is in line with the increase of $\mathrm{sp}^{2} / \mathrm{sp}^{3}$ carbon clusters on each composite surface. Based on the result in Figure 6, the lowest value of the percentage increase of Cs adsorption capacity is observed in $\left[\mathrm{GO}_{70} \mathrm{POM}\right]_{41}$. It is only $6.7 \%$. This might be caused by the decreased oxidized zone $\left(\mathrm{sp}^{2} / \mathrm{sp}^{3}\right.$ hybrid carbon) after the composite was formed (see Table 4). Table 4 shows that the value decreased from $30.3 \%\left(\mathrm{GO}_{\mathrm{c} 70}\right)$ to $28.6 \%\left(\mathrm{GO}_{\mathrm{c} 70} / \mathrm{POM}\right.$ composite). It is also confirmed by the PXRD pattern, which shows the same tendency in $\left[\mathrm{GO}_{70} \mathrm{POM}\right]_{41}$ : that the diffraction has reduced from $11.57^{\circ}$ to $10.99^{\circ}$ if compared with $\mathrm{GO}_{\mathrm{C70}}$ as a precursor material. Some researchers have tried to address the complexity of GO especially to produce a graphene-based hybrid material for diverse applications. For example, one researcher has attempted to control the $\mathrm{sp}^{2} / \mathrm{sp}^{3}$ hybrid carbon structure in GO by a simple ethanol solvothermal method [82]. Furthermore, a similar trend was investigated to enlarge the carbon cluster size by increasing the sonication time [83].

\section{Conclusions}

In this work, the GO-based POM nanocomposite was successfully obtained. The Cs adsorption capacity increased by forming a nanocomposite. The result proposed, first, that the $\mathrm{C} / \mathrm{O}$ ratio of the $\mathrm{GO}$ sample has significantly influenced the characteristic of the GO-POM nanocomposite for the Cs adsorption performance after forming the composite. Specifically, the GO sample, which consists of 70-72 wt \% C element, is a good precursor material to incorporate Dawson-type POM compared to the GO that has $\approx 39$ wt \% C element in their atomic composition. Second, the concentration ratio of 
$\mathrm{GO} / \mathrm{POM}$ in forming a composite material can be considered to maximize the adsorption performance. Additionally, the size and the acidity of the GO also influence the aggregation state. However, further investigation is needed to know the size tunability and the role of acidic properties of GO in different $\mathrm{C} / \mathrm{O}$ compositions for $\mathrm{Cs}$ adsorption. The further calculation was performed to quantify the graphitic zone in each sample. The result revealed that the oxidized zone was enhanced after forming a composite in all samples except $\left[\mathrm{GO}_{70} \mathrm{POM}\right]_{41}$, which shows a different character. Further scrutiny is needed to open the understanding of the role of the oxidative debris (OD) component of GO and the level of hydration of GO for adsorption capacity.

Supplementary Materials: The following are available online at https:/ /www.mdpi.com/article/10 $.3390 / \mathrm{ma14195577/s1}$, Figure S1. SEM measurement (a) $\alpha-\mathrm{K}_{6} \mathrm{P}_{2} \mathrm{~W}_{18} \mathrm{O}_{62} .14 \mathrm{H} 2 \mathrm{O}$ (b) Tungsten element (c) Oxygen element (d) Carbon $\mathrm{K}-\alpha$ X-ray element (e) Secondary electron image. Figure S2. SEM measurement, $\left[\mathrm{GO}_{70} \mathrm{POM}\right]_{41}$ (a) Secondary electron image (b) Carbon K- $\alpha$ X-ray element (c) Oxygen element (d) Tungsten element (e) Aluminum element (f) Cesium element (g) Chloride element. Figure S3. Plausible Interaction between Graphene-Oxide (GO) and Dawson-type Polyoxometalates (POMs). The black and the grey balls corresponds to carbon and hydrogen. The polyhedral model represents to Dawson-type polyoxometalates. The blue dashes indicated of the presence of interaction between GO-POMs. Figure S4. Xrd pattern of $\alpha-\mathrm{K}_{6} \mathrm{P}_{2} \mathrm{~W}_{18} \mathrm{O}_{62} \cdot 14 \mathrm{H}_{2} \mathrm{O}$. Figure S5. XRD pattern of $\mathrm{GO}_{\mathrm{c} 39}$, $\mathrm{GO}_{\mathrm{c} 40}, \mathrm{GOPOM}$ composite before and after Cs adsorption. Figure S6. IR spectra for (a) $\mathrm{GO}_{\mathrm{c} 70}$ (b) $\mathrm{GO}_{\mathrm{c} 72}$ after $\mathrm{Cs}$ adsorption (c) $\mathrm{GO}_{\mathrm{c} 72}$ (d) $\mathrm{GO}_{\mathrm{c} 72}$ after $\mathrm{Cs}$ adsorption (e) $\mathrm{GO}_{\mathrm{c} 39}$ (f) $\mathrm{GO}_{\mathrm{c} 39}$ after Cs adsorption (g) $\mathrm{GO}_{\mathrm{c} 40}(\mathrm{~h}) \mathrm{GO}_{\mathrm{c} 40}$ after Cs adsorption. Figure S7. IR spectra for (a) $\left[\mathrm{GO}_{39} \mathrm{POM}\right]_{18}$ (b) $\left[\mathrm{GO}_{39} \mathrm{POM}\right]_{18}$ after $\mathrm{Cs}$ adsorption (c) $\left[\mathrm{GO}_{39} \mathrm{POM}\right]_{41}$ (d) $\left[\mathrm{GO}_{39} \mathrm{POM}\right]_{41}$ after $\mathrm{Cs}$ adsorption (e) $\left[\mathrm{GO}_{40} \mathrm{POM}\right]_{18}$ (f) $\left[\mathrm{GO}_{40} \mathrm{POM}\right]_{18}$ after Cs adsorption (g) $\left[\mathrm{GO}_{40} \mathrm{POM}\right]_{41}$ (h) $\left[\mathrm{GO}_{40} \mathrm{POM}\right]_{41}$ after Cs adsorption. Figure S8. IR spectra for (a)POM (b)POM after Cs adsorption. Figure S9. Raman spectra (a) Graphite, $\mathrm{GO}_{\mathrm{c} 70}, \mathrm{GO}_{\mathrm{c} 72}, \mathrm{GO}_{\mathrm{c} 39}, \mathrm{GO}_{\mathrm{c} 40},(\mathrm{~b})\left[\mathrm{GO}_{70} \mathrm{POM}\right]_{41}$ and after Cs adsorption. Figure S10. Raman spectra composite (a) $\left[\mathrm{GO}_{39} \mathrm{POM}\right]_{41}$ before and after $\mathrm{Cs}$ adsorption (b) $\mathrm{GO}_{\mathrm{c} 70}$ before and after Cs adsorption. Figure S11. Raman spectra (a) $\mathrm{GO}_{\mathrm{c} 39}$ before and after Cs adsorption (b) $\mathrm{GO}_{\mathrm{c} 40}$ before and after $\mathrm{Cs}$ adsorption. Figure S12. Raman spectra composite $\left[\mathrm{GO}_{72} \mathrm{POM}\right]_{41}$ before and after $\mathrm{Cs}$ adsorption. Figure S13. The composite solution after $C$ s adsorption. Only Composite $\left[\mathrm{GO}_{70} \mathrm{POM}\right]_{41}$ (b) that forms stable solution (black color). Another composite solution shows remains coagulated. The photo was taken after more than one-hour stay at ambient temperature. Figure S14. The GO solution after $\mathrm{Cs}$ adsorption. All GO solutions shows remains coagulated. (a) $\mathrm{GO}_{\mathrm{c} 70}$ and (b) $\mathrm{GO}_{\mathrm{c} 72}$ shows different coagulated behavior with (c) $\mathrm{GO}_{\mathrm{c} 39}$ and (d) $\mathrm{GO}_{\mathrm{c} 40}$. The photo was taken after more than one-hour stay at ambient temperature. Figure S15. Coagulation process after Cs interaction with (a) $\mathrm{GO}_{\mathrm{c} 70}$ and (b) $\mathrm{GO}_{\mathrm{c} 72}$. The photo was taken after more than one-hour stay at ambient temperature. Figure S16. SEM image by using composite (a) $\left[\mathrm{GO}_{70} \mathrm{POM}\right]_{41}$ after Cs adsorption and (b) Cs particle (zoom mode based on figure a). Table $\mathrm{S} 1$. The ratio $\mathrm{I}_{\mathrm{D}} / \mathrm{I}_{\mathrm{G}}$ of Graphene oxide and composite before and after Cs adsorption. Table S2. The crystallize size of GO.

Author Contributions: B.S.N. and S.N. proposed the project; B.S.N., A.K., C.K., T.N. and A.W. investigated and checked the data, B.S.N. and M.N.K.W. calculated and checked the results; B.S.N. and S.N. wrote the manuscript. All authors have read and agreed to the published version of the manuscript.

Funding: This research received no external funding.

Institutional Review Board Statement: Not applicable.

Informed Consent Statement: Not applicable.

Data Availability Statement: Data sharing is not applicable for this article.

Acknowledgments: This work was supported by Phoenix Leader Education Program (PLEP), Chemistry Department, and Makoto Maeda of Natural Science Center for Basic Research and Development (N-BARD), Hiroshima University, Japan.

Conflicts of Interest: There are no conflict to declare. 


\section{References}

1. Nishihara, K.; Yamagishi, I.; Yasuda, K.; Ishimori, K.; Tanaka, K.; Kuno, T.; Inada, S.; Gotoh, Y. Radionuclide release to stagnant water in the Fukushima-1 nuclear power plant. J. Nucl. Sci. Technol. 2014, 52, 301-307. [CrossRef]

2. Konings, R.J.M.; Wiss, T.; Beneš, O. Predicting material release during a nuclear reactor accident. Nat. Mater. 2015, 14, 247-252. [CrossRef] [PubMed]

3. Uchida, S.; Tagami, K. Soil-to-plant transfer factors of fallout 137Cs and native 133Cs in various crops collected in Japan. $J$ Radioanal. Nucl. Chem. 2007, 273, 205-210. [CrossRef]

4. Shizuma, K.; Fujikawa, Y.; Kurihara, M.; Sakurai, Y. Identification and temporal decrease of 137 Cs and 134 Cs in groundwater in Minami-Soma City following the accident at the Fukushima Dai-ichi nuclear power plant. Environ. Pollut. 2018, 234, 1-8. [CrossRef] [PubMed]

5. Koarashi, J.; Atarashi-Andoh, M.; Matsunaga, T.; Sato, T.; Nagao, S.; Nagai, H. Factors affecting vertical distribution of Fukushima accident-derived radiocesium in soil under different land-use conditions. Sci. Total Environ. 2012, 431, 392-401. [CrossRef] [PubMed]

6. $\quad$ Kamiya, K.; Ozasa, K.; Akiba, S.; Niwa, O.; Kodama, K.; Takamura, N.; Zaharieva, E.K.; Kimura, Y.; Wakeford, R. Long-term effects of radiation exposure on health. Lancet 2015, 386, 469-478. [CrossRef]

7. Hasegawa, A.; Tanigawa, K.; Ohtsuru, A.; Yabe, H.; Maeda, M.; Shigemura, J.; Ohira, T.; Tominaga, T.; Akashi, M.; Hirohashi, N.; et al. Health effects of radiation and other health problems in the aftermath of nuclear accidents, with an emphasis on Fukushima. Lancet 2015, 386, 479-488. [CrossRef]

8. Matsuda, N.; Nakashima, S. Radioactive cesium in water and soil and its adsorption to rice plant (interim report). Radiat. Saf. Manag. 2014, 13, 84-91. (in Japanese).

9. TEPCO. The Evaluation Status of Reactor Core Damage at Fukushima Daiichi Nuclear Power Station Units 1 to 3; TEPCO: Tokyo, Japan, 2011; p. 28.

10. Yousefi, T.; Torab-Mostaedi, M.; Moosavian, M.A.; Mobtaker, H.G. Potential application of a nanocompo-site:HCNFe@polymer for effective removal of Cs (I) from nuclear waste. Prog. Nucl. Energy 2015, 85, 631-639. [CrossRef]

11. Jang, S.C.; Kang, S.M.; Haldorai, Y.; Giribabu, K.; Lee, G.W.; Lee, Y.C.; Huh, Y.S. Synergistically strengthened 3D micro-scavenger cage adsorbent for selective removal of radioactive cesium. Sci. Rep. 2016, 6, 1-12.

12. Tamura, K.; Kogure, T.; Watanabe, Y.; Nagai, C.; Yamada, H. Uptake of Cesium and Strontium Ions by Artificially Altered Phlogopite. Environ. Sci. Technol. 2014, 48, 5808-5815. [CrossRef]

13. Eigler, S.; Grimm, S.; Hof, F.; Hirsch, A. Graphene oxide: A stable carbon framework for functionalization. J. Mater. Chem. A. 2013, 1, 1159. [CrossRef]

14. Liu, Z.; Rios-Carvajal, T.; Andersson, M.P.; Ceccato, M.; Stipp, S.L.S.; Hassenkam, T. Ion effects on molecular interaction between graphene oxide and organic molecules. Environ. Sci. Nano 2019, 6, 2281-2291. [CrossRef]

15. Neklyudov, V.V.; Khafizov, N.R.; Sedov, I.; Dimiev, A.M. New insights into the solubility of graphene oxide in water and alcohols. Phys. Chem. Chem. Phys. 2017, 19, 17000-17008. [CrossRef] [PubMed]

16. Konkena, B.; Vasudevan, S. Understanding aqueous dispersibility of graphene oxide and reduced graphene oxide through $\mathrm{p} K_{\mathrm{a}}$ measurements. J. Phys. Chem. Lett. 2012, 3, 867-872. [CrossRef]

17. Ritchie, C.; Streb, C.; Thiel, J.; Mitchell, S.G.; Miras, H.; Long, D.-L.; Boyd, T.; Peacock, R.D.; McGlone, T.; Cronin, L. Reversible Redox Reactions in an Extended Polyoxometalate Framework Solid. Angew. Chem. Int. Ed. 2008, 47, 6881-6884. [CrossRef]

18. Kawahara, R.; Uchida, S.; Mizuno, N. Redox-Induced Reversible Uptake-Release of Cations in Porous Ionic Crystals Based on Polyoxometalate: Cooperative Migration of Electrons with Alkali Metal Ions. Chem. Mater. 2015, 27, 2092-2099. [CrossRef]

19. Uchida, S. Frontiers and progress in cation-uptake and exchange chemistry of polyoxometalate-based compounds. Chem. Sci. 2019, 10, 7670-7679. [CrossRef] [PubMed]

20. Hitose, S.; Uchida, S. Rapid Uptake/Release of Cs+ in Isostructural Redox-Active Porous Ionic Crystals with Large-Molecular-Size and Easily Reducible Dawson-Type Polyoxometalates as Building Blocks. Inorg. Chem. 2018, 57, 4833-4836. [CrossRef] [PubMed]

21. Gall, R.D.; Hill, C.L.; Walker, J.E. Carbon powder and fiber-supported polyoxometalate catalytic materials. Preparation, characterization, and catalytic oxidation of dialkyl sulfides as mustard (HD) analogues. Chem. Mater. 1996, 8, $2523-2527$. [CrossRef]

22. Li, H.; Pang, S.; Feng, X.; Müllen, K.; Bubeck, C. Polyoxometalate assisted photoreduction of graphene oxide and its nanocomposite formation. Chem. Commun. 2010, 46, 6243. [CrossRef] [PubMed]

23. Nugroho, B.S.; Wihadi, M.N.K.; Grote, F.; Eigler, S.; Nakashima, S. Potentiality of Graphene Oxide and Polyoxometalate as Radionuclides Adsorbent to Restore the Environment after Fukushima Disaster: A Mini Review. Indones. J. Chem. 2021, 21, 776-786. [CrossRef]

24. Eigler, S.; Hirsch, A. Chemistry with Graphene and Graphene Oxide-Challenges for Synthetic Chemists. Angezw. Chem. Int. Ed. 2014, 53, 7720-7738. [CrossRef]

25. Dreyer, D.R.; Park, S.; Bielawski, C.W.; Ruoff, R.S. The chemistry of graphene oxide. Chem. Soc. Rev. 2010, 39, 228-240. [CrossRef]

26. Aliyev, E.; Filiz, V.; Khan, M.M.; Lee, Y.J.; Abetz, C.; Abetz, V. Structural Characterization of Graphene Oxide: Surface Functional Groups and Fractionated Oxidative Debris. Nanomaterials 2019, 9, 1180. [CrossRef]

27. Hummers, W.S., Jr.; Offeman, R.E. Preparation of Graphitic Oxide. J. Am. Chem. Soc. 1958, 80, 1339. [CrossRef] 
28. Ranjan, P.; Agrawal, S.; Sinha, A.; Rao, T.R.; Balakrishnan, J.; Thakur, A.D. A Low-Cost Non-explosive Synthesis of Graphene Oxide for Scalable Applications. Sci. Rep. 2018, 8, 1-13. [CrossRef]

29. Mbomekalle, I.M.; Lu, Y.W.; Keita, B.; Nadjo, L. Simple, high yield and reagent-saving synthesis of pure $\alpha-\mathrm{K}_{6} \mathrm{P}_{2} \mathrm{~W}_{18} \mathrm{O}_{62} \cdot 14 \mathrm{H}_{2} \mathrm{O}$. Inorg. Chem. Commun. 2004, 7, 86-90. [CrossRef]

30. Contant, R.; Thouvenot, R. A reinvestigation of isomerism in the Dawson structure: Syntheses and ${ }^{183} \mathrm{~W}$ NMR structural characterization of three new polyoxotungstates $\left[\mathrm{X}_{2} \mathrm{~W}_{18} \mathrm{O}_{62}\right]^{6-}\left(\mathrm{X}=\mathrm{P}^{\mathrm{V}}, \mathrm{As}{ }^{\mathrm{V}}\right)$. Inorganica Chim. Acta 1993, 212, 41-50. [CrossRef]

31. Guerrero-Contreras, J.; Caballero-Briones, F. Graphene oxide powders with different oxidation degree, prepared by synthesis variations of the Hummers method. Mater. Chem. Phys. 2015, 153, 209-220. [CrossRef]

32. Bouša, D.; Luxa, J.; Mazánek, V.; Jankovsky, O.; Sedmidubský, D.; Klímová, K.; Pumera, M.; Sofer, Z. Toward graphene chloride: Chlorination of graphene and graphene oxide. RSC Adv. 2016, 6, 66884-66892. [CrossRef]

33. Cote, L.J.; Kim, J.; Zhang, Z.; Sun, C.; Huang, J. Tunable assembly of graphene oxide surfactant sheets: Wrinkles, over-laps and impacts on thin film properties. Soft Matter 2010, 6, 6096-6101. [CrossRef]

34. Krishnamoorthy, K.; Veerapandian, M.; Yun, K.; Kim, S.-J. The chemical and structural analysis of graphene oxide with different degrees of oxidation. Carbon 2013, 53, 38-49. [CrossRef]

35. Shukla, S.; Saxena, S. Spectroscopic investigation of confinement effects on optical properties of graphene oxide. Appl. Phys. Lett. 2011, 98, 073104. [CrossRef]

36. Kovtyukhova, N.I.; Ollivier, P.J.; Martin, B.R.; Mallouk, T.; Chizhik, S.A.; Buzaneva, E.V.; Gorchinskiy, A.D. Layer-by-Layer Assembly of Ultrathin Composite Films from Micron-Sized Graphite Oxide Sheets and Polycations. Chem. Mater. 1999, 11, 771-778. [CrossRef]

37. Seehra, M.S.; Narang, V.; Geddam, U.K.; Stefaniak, A.B. Correlation between X-ray diffraction and Raman spectra of 16 commercial graphene-based materials and their resulting classification. Carbon 2017, 111, 380-385. [CrossRef]

38. Wang, R.; Dang, L.; Liu, Y.; Jiao, W. Preparation, characterization and photocatalytic activity of Dawson type phosphotungstate/graphene oxide composites. Adv. Powder Technol. 2019, 30, 1400-1408. [CrossRef]

39. Marcano, D.C.; Kosynkin, D.V.; Berlin, J.M.; Sinitskii, A.; Sun, Z.; Slesarev, A.; Alemany, L.B.; Lu, W.; Tour, J.M. Improved Synthesis of Graphene Oxide. ACS Nano 2010, 4, 4806-4814. [CrossRef]

40. Petit, C.; Bandosz, T.J. Graphite Oxide/Polyoxometalate Nanocomposites as Adsorbents of Ammonia. J. Phys. Chem. C 2009, 113, 3800-3809. [CrossRef]

41. Sharma, R.; Chadha, N.; Saini, P. Determination of defect density, crystallite size and number of graphene layers in graphene analogues using X-ray diffraction and Raman spectroscopy. Indian J. Pure Appl. Phys. 2017, 55, 625-629.

42. Dresselhaus, M.S.; Jorio, A.; Filho, A.G.S.; Saito, R. Defect characterization in graphene and carbon nanotubes us-ing Raman spectroscopy. Philos. Trans. R. Soc. A Math. Phys. Eng. Sci. 2010, 368, 5355-5377. [CrossRef]

43. Dimiev, A.M.; Eigler, S. Graphene Oxide: Fundamentals and Applications; John Wiley \& Son, Ltd.: London, UK, 2017.

44. King, A.; Davies, B.R.; Noorbehesht, N.; Newman, P.; Church, T.L.; Harris, A.T.; Razal, J.; Minett, A.I. A New Raman Metric for the Characterisation of Graphene oxide and its Derivatives. Sci. Rep. 2016, 6, 19491. [CrossRef] [PubMed]

45. Su, C.Y.; Xu, Y.; Zhang, W.; Zhao, J.; Liu, A.; Tang, X.; Tsai, C.-H.; Huang, Y.; Li, L.-J. Highly Efficient Restoration of Graphitic Structure in Graphene Oxide Using Alcohol Vapors. ACS Nano 2010, 4, 5285-5292. [CrossRef] [PubMed]

46. Mkhoyan, K.A.; Countryman, A.W.; Sylcox, J.; Stewart, D.A.; Eda, G.; Mattevi, C.; Miller, S.; Chhowalla, M. Atomic and elec-tronic structure of graphene oxide. Nano Lett. 2009, 9, 1058-1063. [CrossRef] [PubMed]

47. Xia, T.; Qi, Y.; Liu, J.; Qi, Z.; Chen, W.; Wiesner, M.R. Cation-inhibited transport of graphene oxide nanomaterials in saturated porous media: The hofmeister effects. Environ. Sci. Technol. 2017, 51, 828-837. [CrossRef]

48. Romanchuk, A.; Slesarev, A.S.; Kalmykov, S.N.; Kosynkin, D.V.; Tour, J. Graphene oxide for effective radionuclide removal. Phys. Chem. Chem. Phys. 2013, 15, 2321-2327. [CrossRef]

49. Parfitt, G.D.; Rochester, C.H. Adsorption from Solution at the Solid/Liquid Interface; Academic Press: London, UK, 1983.

50. Radovic, L.R. Active Sites in Graphene and the Mechanism of $\mathrm{CO}_{2}$ Formation in Carbon Oxidation. J. Am. Chem. Soc. 2009, 131, 17166-17175. [CrossRef]

51. Nair, R.R.; Wu, H.A.; Jayaram, P.N.; Grigorieva, I.V.; Geim, A.K. Unimpeded permeation of water through helium-leak-tightgraphene -based membranes. Science 2012, 335, 442-444. [CrossRef]

52. Ho, T.A.; Striolo, A. Polarizability effects in molecular dynamics simulations of the graphene-water interface. J. Chem. Phys. 2013, 138, 054117. [CrossRef]

53. Guardia, J.S.E.; Marti, J. Specific ion effects in aqueous electrolyte solutions confined within graphene sheets at the na-nometric scale. Phys. Chem. Chem. Phys. 2012, 14, 10799-10808.

54. Dimiev, A.; Alemany, L.B.; Tour, J. Graphene Oxide. Origin of Acidity, Its Instability in Water, and a New Dynamic Structural Model. ACS Nano 2013, 7, 576-588. [CrossRef]

55. Mizuno, N.; Misono, M. Heterogeneous catalysis. Chem. Rev. 1998, 98, 199-217. [CrossRef] [PubMed]

56. Okuhara, T.; Nishimura, T.; Watanabe, H.; Misono, M. Insoluble heteropoly compounds as highly active catalysts for liquid-phase reactions. J. Mol. Catal. 1992, 74, 247-256. [CrossRef]

57. Sánchez-García, I.; Núñez, A.; Bonales, L.J.; Perlado, J.M.; Cobos, J. Study of the adsorption capacity of graphene oxide under gamma radiation in different media. Radiat. Phys. Chem. 2019, 165, 108395. [CrossRef] 
58. Kaewmee, P.; Manyam, J.; Opaprakasit, P.; Le, G.T.T.; Chanlek, N.; Sreearunothai, P. Effective removal of cesium by pristine graphene oxide: Performance, characterizations and mechanisms. RSC Adv. 2017, 7, 38747-38756. [CrossRef]

59. Nemanich, R.J.; Solin, S.A. First- and second-order Raman scattering from finite-size crystals of graphite. Phys. Rev. B 1979, 20, 392-401. [CrossRef]

60. Schwegler, M.A.; Vinke, P.; van der Eijk, M.; van Bekkum, H. Activated carbon as a support for heteropolyanion catalysts. Appl. Catal. A Gen. 1992, 80, 41-57. [CrossRef]

61. Dizaji, A.K.; Mortaheb, H.R.; Mokhtarani, B. Preparation of supported catalyst by adsorption of polyoxometalate on graphene oxide/reduced graphene oxide. Mater. Chem. Phys. 2017, 199, 424-434. [CrossRef]

62. Zhou, D.; Han, B.-H. Graphene-Based Nanoporous Materials Assembled by Mediation of Polyoxometalate Nanoparticles. Adv. Funct. Mater. 2010, 20, 2717-2722. [CrossRef]

63. Liu, Y.; Liu, S.; Lai, X.; Miao, J.; He, D.; Li, N.; Liu, S. Polyoxometalate-Modified Sponge-Like Graphene Oxide Monolith with High Proton-Conducting Performance. Adv. Funct. Mater. 2015, 25, 4480-4485. [CrossRef]

64. Tu, Q.; Pang, L.; Chen, Y.; Zhang, Y.; Zhang, R.; Lu, B.; Wang, J. Effects of surface charges of graphene oxide on neuronal outgrowth and branching. Analyst 2014, 139, 105-115. [CrossRef]

65. Misra, A.; Kozma, K.; Streb, C.; Nymann, M. Beyond Charge Balance: Counter-cation in Polyoxometalate Chemistry. Angezw. Chem. Int. Ed. 2020, 59, 596-612. [CrossRef]

66. Yang, K.; Chen, B.; Zhu, X.; Xing, B. Aggregation, Adsorption, and Morphological Transformation of Graphene Oxide in Aqueous Solutions Containing Different Metal Cations. Environ. Sci. Technol. 2016, 50, 11066-11075. [CrossRef]

67. Zhang, J.; Xiong, C.; Li, Y.; Tang, H.; Meng, X.; Zhu, W. The critical contribution of oxidation debris on the acidic proper-ties of graphene oxide in an aqueous solution. J. Hazard. Mater. 2021, 402, 123552. [CrossRef]

68. Szabo, T.; Maroni, P.; Szilagyi, I. Size-dependent aggregation of graphene oxide. Carbon 2020, 160, 145-155. [CrossRef]

69. Ma, J.C.; Dougherty, D.A. The cation- $\pi$ interaction. Chem. Rev. 1997, 97, 1303-1324. [CrossRef] [PubMed]

70. Xu, Y.; Shen, J.; Zhu, W.; Luo, X.; Chen, K.; Jiang, H. Influence of the water molecule on cation- $\pi$ interaction: Ab initio second order møller-plesset perturbation theory (MP2) calculations. J. Phys. Chem. B 2005, 109, 5945-5949. [CrossRef]

71. Marcus, Y. Ionic radii in aqueous solutions. Chem. Rev. 1988, 88, 1475-1498. [CrossRef]

72. Taniguchi, T.; Kurihara, S.; Tateishi, H.; Hatakeyama, K.; Koinuma, M.; Yokoi, H.; Hara, M.; Ishikawa, H.; Matsumoto, Y. $\mathrm{pH}$-driven, reversible epoxy ring opening/closing in graphene oxide. Carbon 2015, 84, 560-566. [CrossRef]

73. Acik, M.; Mattevi, C.; Gong, C.; Lee, G.; Cho, K.; Chhowalla, M.; Chabal, Y.J. The Role of Intercalated Water in Multilayered Graphene Oxide. ACS Nano 2010, 4, 5861-5868. [CrossRef] [PubMed]

74. Amirov, R.R.; Shayimova, J.; Nasirova, Z.; Dimiev, A.M. Chemistry of graphene oxide. Reactions with transition metal cations. Carbon 2017, 116, 356-365.

75. Lian, B.; de Luca, S.; You, Y.; Alwarappan, S.; Yoshimura, M.; Sahajwalla, V.; Smith, S.C.; Leslie, G.; Joshi, R.K. Extraordinary water adsorption characteristics of graphene oxide. Chem. Sci. 2018, 9, 5106. [CrossRef]

76. Yan, H.; Wu, H.; Li, K.; Wang, Y.; Tao, X.; Yang, H.; Li, A.; Cheng, R. Influence of the Surface Structure of Graphene Oxide on the Adsorption of Aromatic Organic Compounds from Water. ACS Appl. Mater. Interfaces 2015, 7, 6690-6697. [CrossRef]

77. Erickson, K.; Erni, R.; Lee, Z.; Alem, N.; Gannett, W.; Zettl, A. Determination of the Local Chemical Structure of Graphene Oxide and Reduced Graphene Oxide. Adv. Mater. 2010, 22, 4467-4472. [CrossRef] [PubMed]

78. Szabo, T.; Berkesi, O.; Forgó, P.; Josepovits, K.; Sanakis, Y.; Petridis, A.D.; Dékány, I. Evolution of Surface Functional Groups in a Series of Progressively Oxidized Graphite Oxides. Chem. Mater. 2006, 18, 2740-2749. [CrossRef]

79. Ebajo, V.D.; Santos, C.R.L.; Alea, G.V.; Lin, Y.A.; Chen, C.-H. Regenerable Acidity of Graphene Oxide in Promoting Multicomponent Organic Synthesis. Sci. Rep. 2019, 9, 15579. [CrossRef] [PubMed]

80. Kudin, K.N.; Ozbas, B.; Schniepp, H.; Prud'Homme, R.K.; Aksay, I.A.; Car, R. Raman Spectra of Graphite Oxide and Functionalized Graphene Sheets. Nano Lett. 2008, 8, 36-41. [CrossRef]

81. Kim, Y.; Shanmugam, S. Polyoxometalate-reduced graphene oxide hybrid catalyst: Synthesis, structure, and electro-chemical properties. ACS Appl. Mater. Interfaces 2013, 5, 12197-12204. [CrossRef]

82. Wang, S.; Dong, Y.; He, C.; Gao, Y.; Jia, N.; Chen, Z.; Song, W. The role of $\mathrm{sp}^{2} / \mathrm{sp}^{3}$ hybrid carbon regulation in the nonlinear optical properties of graphene oxide materials. RSC Adv. 2017, 7, 53643-53652. [CrossRef]

83. Ahn, S.I. Changing the $\mathrm{sp}^{2}$ Carbon Clusters in Graphene Oxide During Exfoliation. Trans. Electr. Electron. Mater. 2015, 16, 49-52. [CrossRef] 